Review

\title{
Mononuclear first-row transition-metal complexes as molecular catalysts for water oxidation
}

\author{
Ni Wang a, Haoquan Zheng a, Wei Zhang a, Rui Cao a,b,* \\ a Key Laboratory of Applied Surface and Colloid Chemistry, Ministry of Education, School of Chemistry and Chemical Engineering, Shaanxi Normal \\ University, Xi'an 710119, Shaanxi, China \\ b Department of Chemistry, Renmin University of China, Beijing 100872, China
}

\section{A R T I C L E I N F O}

\section{Article history:}

Received 6 November 2017

Accepted 15 December 2017

Published 5 February 2018

\section{Keywords:}

Water oxidation

0-0 bond formation

Oxygen evolution

First-row transition metal

Electrocatalysis

\begin{abstract}
A B S T R A C T
Water oxidation is significant in both natural and artificial photosynthesis. In nature, water oxidation occurs at the oxygen-evolving center of photosystem II, and leads to the generation of oxygen, protons, and electrons. The last two are used for fixation of carbon dioxide to give carbohydrates. In artificial processes, the coupling of water oxidation to evolve $\mathrm{O}_{2}$ and water reduction to evolve $\mathrm{H}_{2}$ is known as water splitting, which is an attractive method for solar energy conversion and storage. Because water oxidation is a thermodynamically uphill reaction and is kinetically slow, this reaction causes a bottleneck in large-scale water splitting. As a consequence, the development of new and efficient water oxidation catalysts (WOCs) has attracted extensive attention. Recent efforts have identified a variety of mononuclear earth-abundant transition-metal complexes as active and stable molecular WOCs. This review article summarizes recent progress in research on mononuclear catalysts that are based on first-row transition-metal elements, namely manganese, iron, cobalt, nickel, and copper. Particular attention is paid to catalytic mechanisms and the key $0-0$ bond formation steps. This information is critical for designing new catalysts that are highly efficient and stable.
\end{abstract}

(c) 2018, Dalian Institute of Chemical Physics, Chinese Academy of Sciences.

Published by Elsevier B.V. All rights reserved.

\section{Introduction}

The use and burning of fossil fuels have resulted in a series of energy and environmental problems. This has made it necessary to find and use new energy resources that are sustainable, clean, and environmentally benign [1-4]. Solar energy is the most promising energy source for future consumption. Artificial photosynthesis, achieved via water splitting, enables the harvesting and use of solar energy by converting it to chemical energy [5-8]. This process mimics natural photosynthesis, in which solar energy is used to oxidize water, with evolution of $\mathrm{O}_{2}$ and generation of protons and electrons. The released $\mathrm{O}_{2}$ is essential for living beings, and the protons and electrons extracted from water participate in the reduction of carbon dioxide to produce carbohydrates, a process by which solar energy is stored in chemical forms. If the protons and electrons combine directly to produce $\mathrm{H}_{2}$, this process enables light-driven water splitting to $\mathrm{O}_{2}$ and $\mathrm{H}_{2}$ gases. The production of $\mathrm{H}_{2}$ gas by this method is clean and carbon-free [9-11], and reaction of the produced $\mathrm{H}_{2}$ with $\mathrm{O}_{2}$ (i.e., in fuel cells) generates electrical energy with water as the only product. Water splitting is therefore important in new energy technologies.

Water oxidation, which is one of the half reactions in water splitting, is challenging both thermodynamically $\left(2 \mathrm{H}_{2} \mathrm{O} \rightarrow \mathrm{O}_{2}+\right.$ $4 \mathrm{H}^{+}+4 \mathrm{e}^{-}, \Delta E=1.23 \mathrm{~V}$ vs normal hydrogen electrode (NHE)) and kinetically (extensive rearrangement of atoms) [1,3]. Wa-

\footnotetext{
* Corresponding author. E-mail: ruicao@ruc.edu.cn

This work was supported by Thousand Talents Program" of China, the National Natural Science Foundation of China (21101170, 21573139, and 21773146), the Fundamental Research Funds for the Central Universities, and the Research Funds of Shaanxi Normal University.

DOI: 10.1016/S1872-2067(17)63001-8 | http://www.sciencedirect.com/science/journal/18722067 | Chin. J. Catal., Vol. 39, No. 2, February 2018
} 
ter oxidation therefore limits the overall efficiency of water splitting. Catalysts are required for water oxidation. Much effort has been made recently to design and develop efficient and stable catalysts for this process [12-49]. In general, catalysts can be divided into material catalysts and molecular catalysts. Molecular complexes have the following advantages over material catalysts. (1) Their structures are much clearer and are much easier to modify. (2) They are more amenable to mechanistic studies in solution by various spectroscopic methods. (3) The structure-function relationships of molecular catalysts can be systematically studied. (4) They can be easily integrated into molecular assemblies for the construction of practical water oxidation devices. (5) The key 0-0 bond formation step can be better understood both experimentally and theoretically in molecular systems.

Recently, mononuclear metal complexes have been found to be active and stable catalysts for water oxidation [3,50,51]. Although ruthenium and iridium complexes show high activities [52-70], the low natural abundances and high costs of these noble-metal elements limit their widespread applications. The use of cheap and efficient catalysts based on earthabundant metal elements is therefore desirable. This review article summarizes recent rapid progress in mononuclear WOCs based on first-row transition-metal elements, namely manganese, iron, cobalt, nickel, and copper. Particular attention is paid to catalytic mechanisms and the key $0-0$ bond formation steps. Progress in this area has enabled advances in catalyst design. We believe that such information is critical for designing new catalysts that are more efficient and stable than currently available catalysts.

\section{First-row transition-metal mononuclear catalysts}

\subsection{Manganese catalysts}

Nature uses a $\mathrm{Mn}_{4} \mathrm{CaO}_{x}$ cluster to catalyze the oxidation of water to $\mathrm{O}_{2}$ [71-73]. On the basis of this natural process, many Mn complexes have been synthesized and investigated for use as WOCs. The first well-studied mononuclear Mn catalyst for water oxidation was reported by Sun and co-workers in 2007 [74]. The Mn-corrole complex 1 (Fig. 1) was designed as a bio-inspired model of the oxygen-evolving center of photosystem II. Cyclic voltammetry (CV) of $\mathbf{1}$ in dichloromethane showed two reversible redox events at $E_{1 / 2}=-0.32$ and $0.61 \mathrm{~V}$ (vs $\mathrm{Ag} / \mathrm{Ag}^{+}$), assigned to $\mathrm{Mn}^{\mathrm{II}} / \mathrm{Mn}^{\mathrm{III}}$ and $\mathrm{Mn}^{\mathrm{III}} / \mathrm{Mn}^{\mathrm{IV}}$, respectively. This low oxidation potential of $\mathrm{Mn}{ }^{\mathrm{III}} / \mathrm{Mn}^{\mathrm{IV}}$ indicates that it can be easily oxidized to its high-valent state for water oxidation. On addition of $n$-Bu4 $\mathrm{NOH}$, the cyclic voltammogram of $\mathbf{1}$ displayed an additional peak at $E_{\mathrm{pa}}=0.79 \mathrm{~V}$ (vs $\mathrm{Ag} / \mathrm{Ag}^{+}$). This new peak arises from water oxidation and the evolved $\mathrm{O}_{2}$ was detected by electrochemical reduction at $-1.29 \mathrm{~V}\left(\mathrm{vs} \mathrm{Ag} / \mathrm{Ag}^{+}\right)$. Privalov and Sun [75] subsequently reported a detailed computational study of $\mathrm{O}-\mathrm{O}$ bond formation with the monomeric $\mathrm{Mn}$-corrole $\mathbf{1}$. The formally $\mathrm{Mn}^{\mathrm{V}}=0$ species was suggested to be responsible for $\mathrm{O}-\mathrm{O}$ bond formation. This $\mathrm{d}^{2} \mathrm{Mn}$-oxo species has a closed-shell singlet ground state, but is converted to a quintet $\mathrm{Mn}^{\mathrm{IV}}$-oxyl species in a polar solvent. Two $\mathrm{O}-\mathrm{O}$ bond
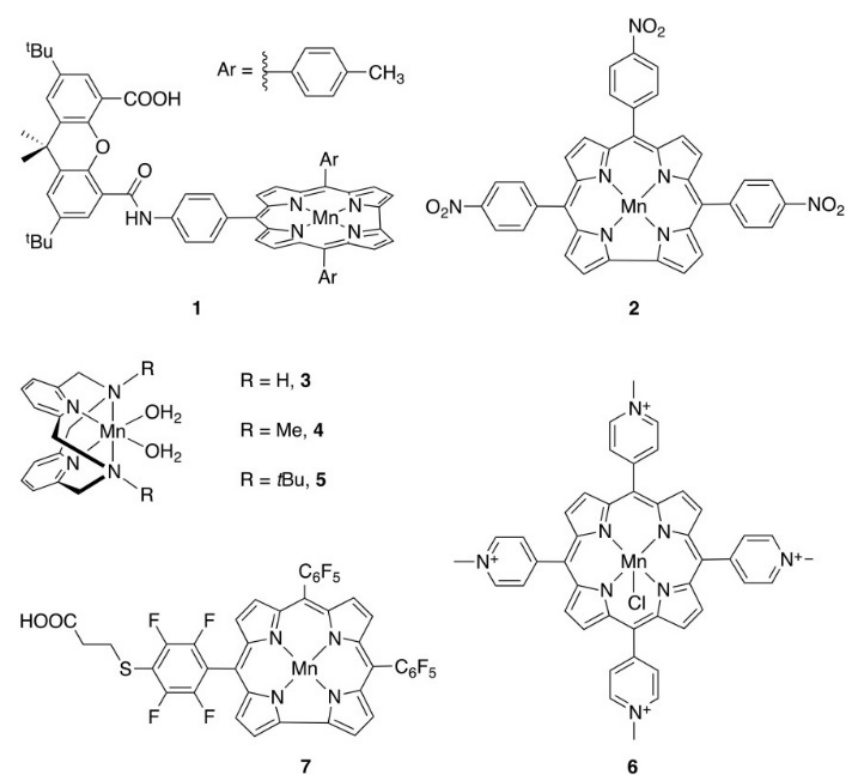

Fig. 1. Mn-based molecular catalysts for water oxidation.

formation processes were compared: a concerted pathway and a two-step pathway via coordination of a hydroxide anion on the $\mathrm{Mn}$ ion to produce $\mathrm{MnOOH}$. A density functional theory (DFT) study showed that the concerted pathway was more favorable, with an activation energy barrier of 8-10 kcal/mol. However, it should be noted that the energy difference between these two processes is moderate. It is therefore possible that the reaction proceeds via both reaction pathways simultaneously.

This $0-0$ bond formation step was further probed by Sun and co-workers [76], who used a Mn complex with 5,10,15tris(4-nitrophenyl)corrole (2, Fig. 1) to investigate nucleophilic attack by a hydroxide anion on a $\mathrm{Mn}^{\mathrm{V}}=\mathrm{O}$ unit. The oxidation of 2 with $t$ - $\mathrm{BuOOH}$ afforded the $\mathrm{MnV}=0$ species, which was characterized using various spectroscopic methods. In a subsequent reaction with $n-\mathrm{Bu}_{4} \mathrm{NOH}, \mathrm{O}_{2}$ was rapidly evolved. The $\mathrm{Mn}^{\mathrm{IV}}-\mathrm{OO}^{-}$ intermediate, which is probably formed by nucleophilic attack of a hydroxide anion on the $\mathrm{Mn}^{\mathrm{V}}=\mathrm{O}$ unit, followed by one-electron oxidation, was examined using electronic absorption spectroscopy, high-resolution mass spectrometry (HRMS), and isotopic ${ }^{180} \mathrm{O}$-labeling experiments. The results show that one atom of $\mathrm{O}_{2}$ came from $n-\mathrm{Bu}_{4} \mathrm{NOH}$ and the other came from water. On the basis of these experiments, Sun and co-workers proposed the reaction mechanism shown in Fig. 2. This work is significant because it shows that nucleophilic attack of a hydroxide anion on a $\mathrm{Mn}^{\mathrm{V}}=\mathrm{O}$ unit can form an $\mathrm{O}-\mathrm{O}$ bond, and this sheds light on water oxidation at the oxygen-evolving center of photosystem II.

In 2010, Anxolabéhère-Mallart and co-workers [77] reported activation of a water molecule by electrochemical oxidation of a $\mathrm{Mn}^{\mathrm{II}}-\mathrm{OH}_{2}$ complex to a $\mathrm{Mn}^{\mathrm{IV}}=\mathrm{O}$ species. The intermediates $\mathrm{Mn}^{\mathrm{II}}-\mathrm{OH}_{2}, \mathrm{Mn}^{\mathrm{III}}-\mathrm{OH}$, and $\mathrm{Mn}^{\mathrm{IV}}=\mathrm{O}$ were all investigated. Extended X-ray absorption fine structure analysis showed a gradual shortening of the $\mathrm{Mn}-\mathrm{O}$ bond from $\mathrm{Mn}^{\mathrm{II}}-\mathrm{OH}_{2}$ to $\mathrm{Mn}^{\mathrm{III}}-\mathrm{OH}$ and $\mathrm{Mn}^{\mathrm{IV}}=\mathrm{O}$. Experimental results and DFT calculations suggested that the $\mathrm{Mn}^{\mathrm{IV}}=\mathrm{O}$ unit is best described as 


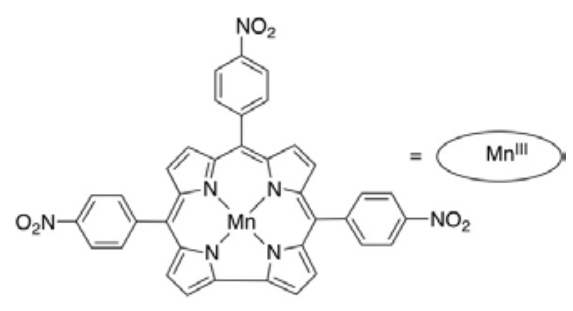

2

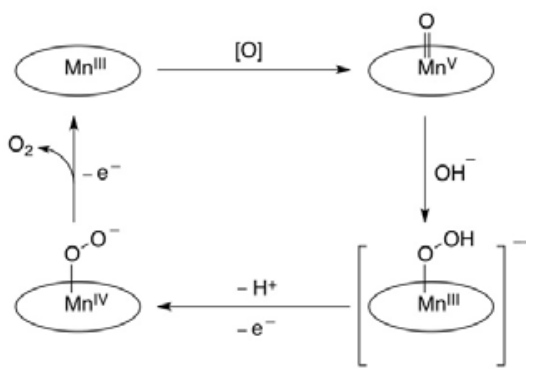

Fig. 2. A possible $\mathrm{O}_{2}$ evolution mechanism mediated with Mn corrole 2 . Redrawn from Ref. [76]. Copyright 2009 American Chemical Society.

$\mathrm{Mn}^{\mathrm{III}}$-oxyl. Although catalytic water oxidation was not observed using this Mn complex, this work elucidates the activation of a water molecule on a Mn center, which is relevant to the natural water oxidation system.

Another study of $\mathrm{Mn}^{\mathrm{V}}=\mathrm{O}$ species, by Borovik and co-workers [78], confirmed its participation in water oxidation. In this system, the Mn center rather than the oxygen ligand was oxidized, giving $\mathrm{MnV}=\mathrm{O}$ instead of a $\mathrm{Mn}^{\mathrm{IV}}$-oxyl radical. Isotopic labeling experiments using ${ }^{17} 0$-labeled samples showed appreciable spin density on the oxo ligand in $\mathrm{Mn}^{\mathrm{V}}=0$; this suggests a possible radical coupling reaction of this species during $0-0$ bond formation.

In 2014, Smith and co-workers [79] reported the catalytic activity of $\mathrm{Mn}^{\mathrm{II}}$ complexes with pyridinophane (3-5, Fig. 1) in $\mathrm{O}_{2}$ formation. Complexes $\mathbf{3}$ and $\mathbf{4}$ with small substituents on the nitrogen $(\mathrm{R}=\mathrm{H}$ and $\mathrm{Me})$ catalyzed the disproportionation of $\mathrm{H}_{2} \mathrm{O}_{2}$, whereas complex 5, which has a bulky $t$-Bu substituent, was not active in $\mathrm{H}_{2} \mathrm{O}_{2}$ disproportionation but was active in catalytic water oxidation to evolve $\mathrm{O}_{2}$. The onset potential for catalytic water oxidation with $\mathbf{5}$ is about $1.30 \mathrm{~V}$ (vs NHE) at $\mathrm{pH}$ $=12.2$, corresponding to an overpotential of about $0.8 \mathrm{~V}$. Controlled potential electrolysis of $\mathbf{5}$ at $1.23 \mathrm{~V}$ (vs NHE) gave turnover numbers (TONs) of 16-24 with Faradaic efficiencies of (74-81)\%. Smith and co-workers [80] used DFT methods to investigate the water oxidation mechanism in the reaction with 5 as the catalyst. A MnV-bis(oxo) species was proposed as the catalytically active species, from which the $0-0$ bond was formed via an intramolecular radical coupling reaction, with a calculated reaction energy barrier of $14.7 \mathrm{kcal} / \mathrm{mol}$ (Fig. 3). It was suggested that the pyridinophane ligand is important for various reasons, e.g., (1) it provides an appropriate electronic environment for accessing multiple oxidation and spin states and (2) it has the right geometry and flexibility for creating a cis divacant octahedral environment for $0-0$ coupling.

Liao and co-workers [81] also used DFT methods to investigate the mechanism of water oxidation catalyzed by $\mathbf{5}$. Two

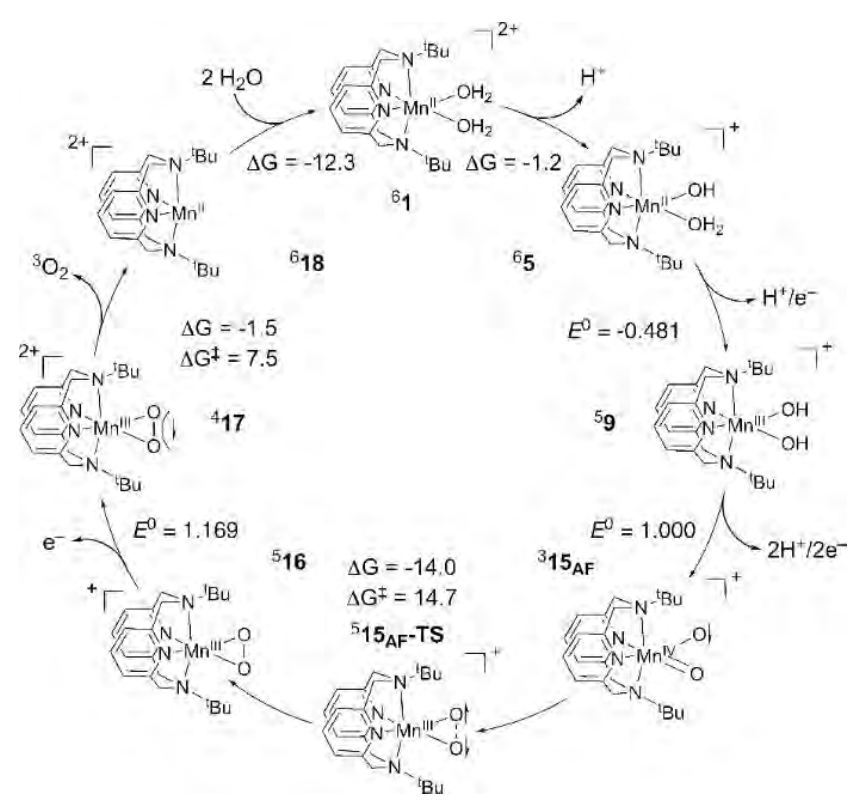

Fig. 3. A proposed catalytic cycle for water oxidation with Mn complex 5. Reprinted with permission from Ref. [80]. Copyright 2017 American Chemical Society.

pathways can lead to the formation of an $0-0$ bond from the $\mathrm{Mn}^{\mathrm{V}}$-bis(oxo) species, i.e., either direct intramolecular coupling of the two oxo ligands or nucleophilic attack of the $\mathrm{Mn}^{\mathrm{V}}=\mathrm{O}$ unit by a water molecule. For the direct coupling pathway, the calculated reaction energy barrier was $13.8 \mathrm{kcal} / \mathrm{mol}$, and for the pathway involving nucleophilic attack by water, the calculated energy barrier was $13.1 \mathrm{kcal} / \mathrm{mol}$. In the latter mechanism, one oxo ligand is attacked by a water molecule and the other oxo ligand functions as a base and accepts a proton from the water molecule. Both pathways could therefore contribute to catalysis.

In 2014, D’Eramo and co-workers [82] reported the water oxidation activity of a water-soluble $\mathrm{Mn}^{\mathrm{III}}$-chloride complex with 5,10,15,20-tetrakis(4- $N$-methylpyridyl)porphyrin (6, Fig. 1). Complex 6 catalyzed water oxidation in aqueous phosphate buffer solutions at both $\mathrm{pH}=7$ and 10 . However, the chloride anions of the $\mathrm{Mn}^{\mathrm{III}}$-porphyrin were also oxidized during this process, and the catalytic current decreased by approximately $40 \%$ in the case of a chloride-free $\mathrm{Mn}^{\mathrm{III}}$-porphyrin.

In 2016, Dey and co-workers [83] reported that Mn-corrole 7 (Fig. 1) was active in water oxidation in strong basic aqueous solutions. Two oxidation events appeared, at 0.53 and $0.78 \mathrm{~V}$ (vs $\mathrm{Ag} / \mathrm{AgCl}$ ), in the cyclic voltammogram of $\mathbf{7}$ in acetonitrile, corresponding to $\mathrm{Mn}^{\mathrm{IV}} / \mathrm{Mn}^{\mathrm{III}}$ and $\mathrm{MnV} / \mathrm{Mn}^{\mathrm{IV}}$, respectively. An additional irreversible wave appeared at $1.38 \mathrm{~V}$ (vs $\mathrm{Ag} / \mathrm{AgCl}$ ). Significantly, the intensity of this wave increased on addition of a $\mathrm{NaOH}$ aqueous solution, indicating catalytic $\mathrm{O}_{2}$ evolution. The function $\left(i_{\text {cat }} / i_{\mathrm{p}}\right)^{2}$ (where $i_{\text {cat }}$ is the catalytic current, $i_{\mathrm{p}}$ is the non-catalytic peak current) increased linearly with $\mathrm{NaOH}$ concentration, to give a pseudo-first-order rate constant of $11.4 \mathrm{~s}^{-1}$ with $25 \mathrm{mmol} / \mathrm{L} \mathrm{NaOH}$. Catalytic water oxidation was further confirmed by using an edge-plane pyrolytic graphite electrode surface-loaded with complex $\mathbf{7}$ in strong basic solutions. At $\mathrm{pH}$ $=11.0$, large catalytic currents were observed at potentials 
$>1.30 \mathrm{~V}$ (vs Ag/AgCl). Controlled potential electrolysis of 7 at $1.40 \mathrm{~V}$ (vs Ag/AgCl) gave a TON of $1.90 \times 10^{4}$ over $11.1 \mathrm{~h}$ and a turnover frequency (TOF) of $0.47 \mathrm{~s}^{-1}$. The corresponding Faradaic efficiency for $\mathrm{O}_{2}$ evolution was calculated to be $82 \%$.

\subsection{Iron catalysts}

Iron is widely used for $\mathrm{O}_{2}$ activation in nature [1], and its catalytic properties in water oxidation have attracted much recent attention. In 2010, Collins and co-workers [84] reported the first examples of mononuclear Fe complexes for water oxidation. A series of $\mathrm{Fe}^{\mathrm{III}}$ complexes with tetraamido macrocyclic ligands (Fe-TAML, 8a-8e, Fig. 4) were synthesized and examined. Complex 8a was inactive, but $\mathbf{8 b}-\mathbf{8 e}$ were active. Complex 8e showed the highest activity, with a TOF of $1.3 \mathrm{~s}^{-1}$; this shows that electron-withdrawing ligands favor this process. Previous studies by Collins and co-workers [85] suggested that $\mathrm{Fe}^{\mathrm{V}}=0$ could be generated in the Fe-TAML system. This indicates that a high-valent $\mathrm{Fe}^{\mathrm{V}}=0$ species $(S=1 / 2)$ is probably the key intermediate in water oxidation catalysis. Cramer and co-workers [86] used DFT methods to investigate the reaction mechanism with $\mathbf{8 e}$ as the catalyst. Water nucleophilic attack on a $\mathrm{Fe}^{\mathrm{V}}=\mathrm{O}$ unit leads to $\mathrm{O}-\mathrm{O}$ bond formation. It is worth noting that the supporting TAML ligand must be oxidized by one electron prior to this water nucleophilic attack. Liao and co-workers [87] also studied this process using DFT methods. The calculated activation energy barrier for water nucleophilic attack on $\mathrm{TAML}^{\cdot+}-\mathrm{Fe}^{\mathrm{V}}=0$ was $15.4 \mathrm{kcal} / \mathrm{mol}$.

In a subsequent study, Kitchin and co-workers [88] immobilized a Fe-TAML complex on glassy carbon or carbon paper for electrocatalytic water oxidation, and obtained a TOF of 0.081
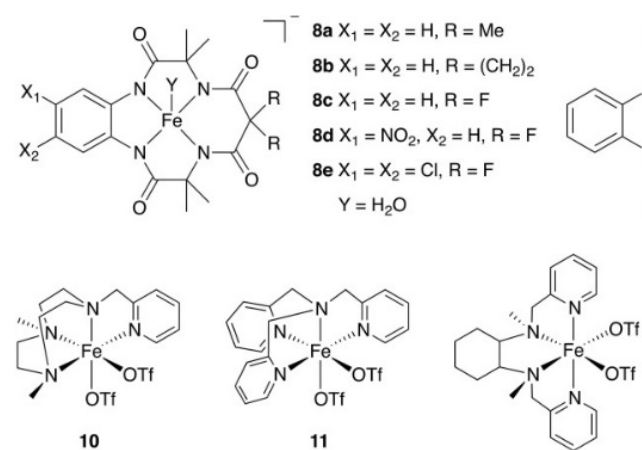

12
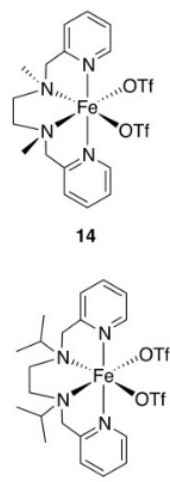

18
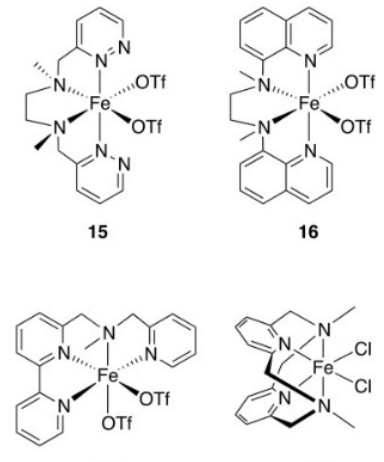

19

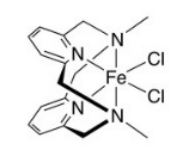

20

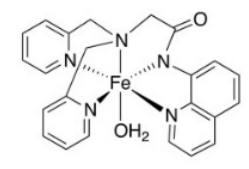

21

Fig. 4. Fe-based molecular catalysts for water oxidation.



13

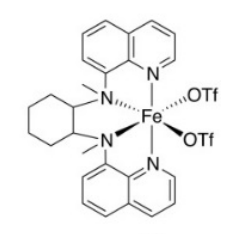

17 $\mathrm{s}^{-1}$ with a $45 \%$ Faradaic efficiency. Dhar and co-workers [89] reported photochemical water oxidation with a biuret-modified Fe-TAML complex (9, Fig. 4). The maximum TON was 220 , and the TOF was $0.76 \mathrm{~s}^{-1}$. A Fe $=0$ species was photochemically generated; its formation was supported by electron paramagnetic resonance, ultraviolet-visible (UV-Vis), and HRMS studies. This $\mathrm{Fe}^{\mathrm{V}}=\mathrm{O}$ intermediate is responsible for $\mathrm{O}-\mathrm{O}$ bond formation. The proposed reaction mechanism with complex 9 is shown in Fig. 5. Irradiation at $440 \mathrm{~nm}$ in the presence of $\mathrm{Na}_{2} \mathrm{~S}_{2} \mathrm{O}_{8}$ and $\left.[\mathrm{Ru} \text { (pyridyl) }]_{3}\right]^{2+}$ transforms the Fe ${ }^{\mathrm{III}}$-aqua complex into $\mathrm{Fe}^{\mathrm{V}}=\mathrm{O}$ via a two-step proton-coupled electron-transfer (PCET) process. The $\mathrm{Fe}^{\mathrm{V}}=0$ undergoes water nucleophilic attack to form the $\mathrm{O}-\mathrm{O}$ bond. The resulting $\mathrm{Fe}^{\mathrm{III}}-\mathrm{OOH}$ is further oxidized by two electrons to evolve $\mathrm{O}_{2}$ and regenerate the starting $\mathrm{Fe}^{\mathrm{III}}$-aqua complex.

In 2011, Fillol and co-workers [90] examined a series of mononuclear Fe complexes for use as water oxidation catalysts. These Fe complexes contained various nitrogen-based neutral tetradentate or pentadentate ligands. Fe complexes 10-14, which have two vacant coordination sites in a cis arrangement, were active (Fig. 4), whereas those containing two trans sites or only one vacant site were inactive in water oxidation. $\mathrm{A} \mathrm{Fe} \mathrm{Fe}^{\mathrm{IV}}=\mathrm{O}$ intermediate was suggested on the basis of UV-Vis spectroscopic and ESI-MS results in titration experiments with cerium

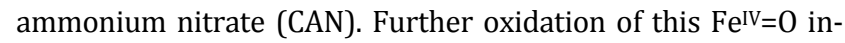
termediate with $\mathrm{CAN}$ generated $\mathrm{a} \mathrm{Fe}^{\mathrm{V}}=\mathrm{O}$ species, which rapidly reacted with a water molecule to form the $\mathrm{O}-\mathrm{O}$ bond. TONs > 1000 were obtained. On the basis of these results, the authors proposed the reaction mechanism shown in Fig. 6.

In a subsequent study, Fillol and co-workers [91] studied the reaction mechanism and the electronic effects of these Fe-based catalysts on water oxidation. Complex $\mathbf{1 0}$ and a family of its derivatives with various substituents on the pyridine ring were examined. Electron-withdrawing groups at the para position of the pyridine ring were favorable. In addition, it was found that a key intermediate was formed between $\mathrm{Fe}^{\mathrm{IV}}=0$ and $\mathrm{Ce}^{\mathrm{IV}}$ prior to formation of a $\mathrm{Fe}^{\mathrm{V}}=\mathrm{O}$ species. UV-Vis titration and

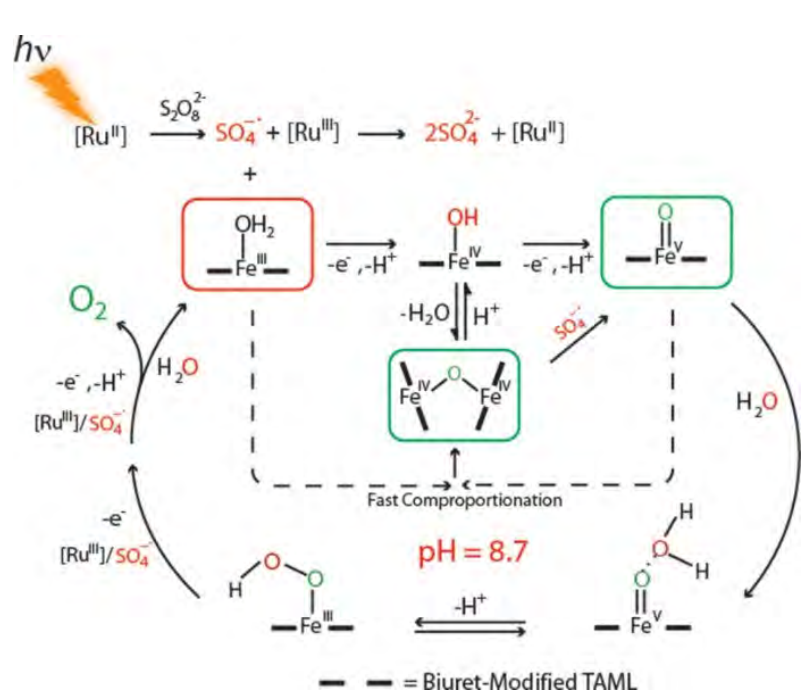

Fig. 5. A proposed photocatalytic water oxidation mechanism with biuret-modified Fe-TAML 9. Reprinted with permission from Ref. [89]. Copyright 2014 American Chemical Society. 

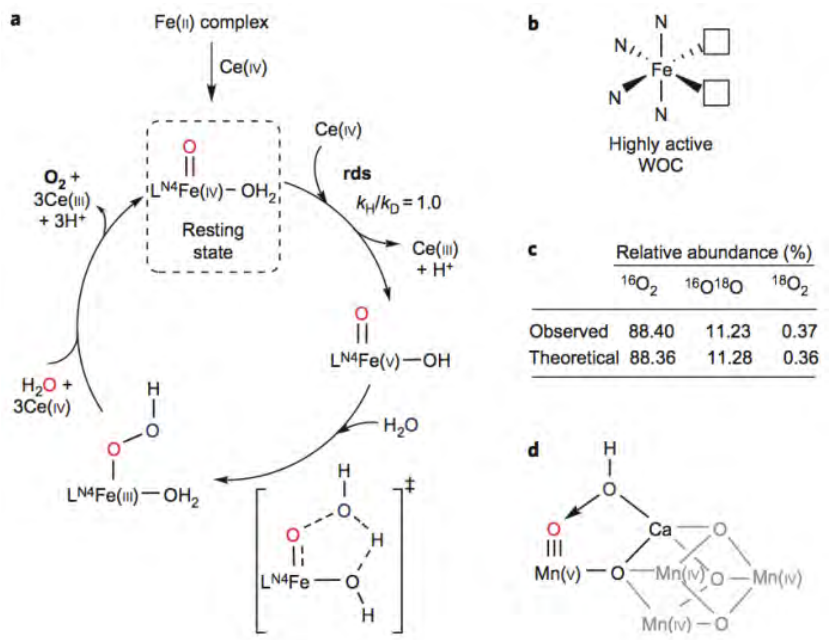

Fig. 6. A proposed water oxidation mechanism with Fe complexes of tetradentate N ligands containing two cis vacant sites. Reprinted with permission from Ref. [90]. Copyright 2011 Macmillan Publishers Limited.

kinetic studies suggested that this intermediate was $\mathrm{Fe}^{\mathrm{IV}}(\mathrm{O})-(\mathrm{OH})-\mathrm{Ce}^{\mathrm{IV}}$, with a bridging hydroxyl group. Fe ${ }^{\mathrm{IV}}(\mathrm{O})-$ $(\mathrm{OH})-\mathrm{Ce}^{\mathrm{IV}}$ was converted to $\mathrm{Fe}^{\mathrm{V}}(\mathrm{O})-(\mathrm{OH})-\mathrm{Ce}^{\mathrm{III}}$, and a water molecule subsequently attacked the resulting $\mathrm{Fe}^{\mathrm{V}}=\mathrm{O}$ unit to form the $\mathrm{O}-\mathrm{O}$ bond. This proposal was supported by DFT calculations. The presence of $\mathrm{Fe}^{\mathrm{IV}}(\mathrm{O})-(\mathrm{OH})-\mathrm{Ce}^{\mathrm{IV}}$ was confirmed experimentally by cryospray ionization HRMS and resonance Raman spectroscopy [92]. On the basis of these results, the authors proposed a possible reaction mechanism for the formation of this $\mathrm{Fe}^{\mathrm{IV}}-\mathrm{O}-\mathrm{Ce}^{\mathrm{IV}}$ intermediate and its subsequent conversion for $\mathrm{O}-\mathrm{O}$ bond formation (Fig. 7). The identification of this $\mathrm{Fe}^{\mathrm{IV}}-\mathrm{O}-\mathrm{Ce}^{\mathrm{IV}}$ intermediate, which is responsible for the key $\mathrm{O}-\mathrm{O}$ bond-forming step, provides new insights into the analogous $\mathrm{Mn}^{\mathrm{V}}-\mathrm{O}-\mathrm{Ca}^{\mathrm{II}}$ unit in the oxygen-evolving center of photosystem II.

Bartlett and co-workers [93] reported that anchoring a phosphonate-derivatized Fe complex 12 on $\mathrm{WO}_{3}$ through co-

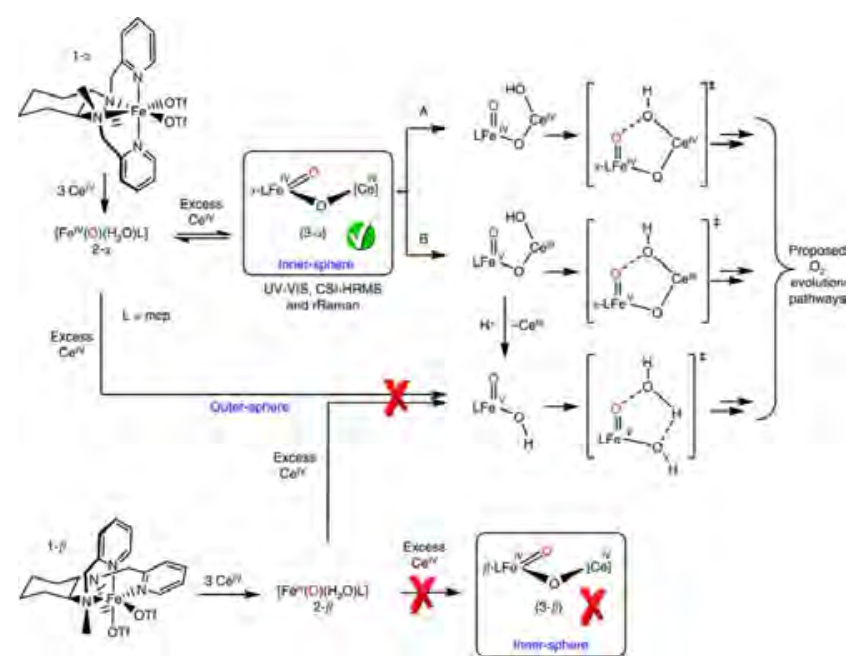

Fig. 7. A proposed water oxidation mechanism with Fe complex 12. Reprinted with permission from Ref. [92]. Copyright 2015 Macmillan Publishers Limited. valent bonds improved photoelectrochemical water oxidation. After anchoring the $\mathrm{Fe}$ complex on the $\mathrm{WO}_{3}$ electrode, an increase in the photocurrent density was observed, indicating a fast chemical reaction in the presence of the Fe catalyst. In addition to the increased photocurrent density, a significant increase in the Faradaic efficiency was achieved. The Fe-modified $\mathrm{WO}_{3}$ electrode gave a Faradaic efficiency of $(79 \pm 9) \%$ for $\mathrm{O}_{2}$ evolution, compared with $(56 \pm 7) \%$ for the unmodified $\mathrm{WO}_{3}$ electrode.

Similar Fe complexes containing two cis vacant coordination sites were reported to be active in water oxidation [94-96]. In 2013, Yang and co-workers [94] examined the water oxidation activities of a series of Fe complexes with hydrogen-bonding functionalities incorporated into the second coordination sphere. The results showed that complex 15 (Fig. 4) was the most active catalyst in this series, which suggests that intramolecular pendant base groups are favorable for water oxidation. In 2013, Fukuzumi and co-workers [95] reported two Fe complexes, i.e., 16 and 17 (Fig. 4), which can catalyze water oxidation by CAN. The TONs for $\mathrm{O}_{2}$ evolution were $80 \pm 10$ and $20 \pm$ 5 for 16 and 17, respectively. Significantly, the authors showed that under acidic conditions these Fe complexes acted as true homogeneous catalysts in water oxidation, whereas under basic conditions $\mathrm{Fe}(\mathrm{OH})_{3}$ nanoparticles derived from the $\mathrm{Fe}$ complexes acted as heterogeneous catalysts. Ligand dissociation and oxidation are responsible for the decomposition of these Fe complexes under catalytic conditions. In 2016, Thapper and co-workers [96] reported that Fe complexes 18 and 19 (Fig. 4) are active WOCs. The addition of CAN to an aqueous solution of $\mathbf{1 8}$ or 19 resulted in formation of semi-stable $\mathrm{Fe}^{\mathrm{IV}}$ $=0$ species. However, the catalytic activities of these two complexes are much lower than those of their analogs.

In 2015, Che and co-workers reported a Fe complex with $N, N$-dimethyl-2,11-diaza[3,3](2,6)pyridinophane (20, Fig. 4) and its catalytic activity in water oxidation with a variety of chemical oxidants such as $\mathrm{CAN}, \mathrm{NaIO}_{4}$, and oxone [97]. Spectroscopic data and ${ }^{180} \mathrm{O}$-labelling experiments suggested that $\mathrm{Fe}^{\mathrm{IV}}=\mathrm{O}$ and/or $\mathrm{Fe}^{\mathrm{V}}=\mathrm{O}$ intermediates were involved in the catalytic cycle. The reaction mechanisms differed, depending on the chemical oxidant. With CAN as the oxidant at $\mathrm{pH}=1, \mathrm{Fe}^{\mathrm{IV}}=0$ was identified by ESI-MS and UV-Vis spectroscopy. The $\mathrm{O}_{2}$ evolution rate had a linear dependence on the concentrations of both 20 and CAN. In contrast, when $\mathrm{NaIO}_{4}$ or oxone was used as the oxidant at $\mathrm{pH}=1$, ESI-MS suggested that $\mathrm{Fe}^{\mathrm{V}}=0$, with the formula $\left[\mathrm{FeV}(\mathrm{O})_{2}\right]^{+}$, was involved. DFT calculations showed that this $\left[\mathrm{FeV}^{\mathrm{V}}(\mathrm{O})_{2}\right]^{+}$intermediate oxidized water to generate $\mathrm{O}_{2}$, with a calculated activation energy barrier of $15.7 \mathrm{kcal} / \mathrm{mol}$.

In 2015, Thummel and co-workers [98] compared the water oxidation activities of mononuclear and $\mu$-oxo-bridged dinuclear Fe ${ }^{I I I}$ complexes. The $\mu$-oxo-bridged dinuclear complex, with a TOF of $7920 \mathrm{~h}^{-1}$, was much more active than the mononuclear analog, with a TOF of only $842 \mathrm{~h}^{-1}$. Kinetic and spectroscopic studies suggested that the dinuclear Fe ${ }^{\text {III }}$ complex remained intact in solution during the catalytic process. A $\mathrm{Fe}^{\mathrm{III}} \mathrm{Fe}^{\mathrm{V}}=\mathrm{O}$ intermediate was proposed as the catalytically active species, which reacted with water to produce $\mathrm{O}_{2}$.

Thapper and co-workers [99] reported that Fe-Py5 (Py5 = 
pyridine-2,6-diylbis[di(pyridin-2-yl)methanol]) complexes, which contain only one vacant site, were active WOCs. However, the authors proposed that the Py5 ligand underwent de-coordination of one pyridyl group to generate an active species with two open/labile coordination sites available for water binding and activation. These pyridyl-based pentadentate ligands therefore resemble the previously described tetradentate ligands for Fe coordination.

In 2014, Meyer and co-workers [100] reported a six-coor-


water oxidation in a mixed solution of propylene carbonate and water. The results of electrochemical and kinetic studies suggested that this $\mathrm{Fe}^{\mathrm{III}}$-aqua complex was first oxidized to $\mathrm{Fe}^{\mathrm{V}}=\mathrm{O}$, which then reacted with a water molecule via a reaction that was first order with respect to both the catalyst and water. The determined $k_{0}$ was $0.035(4) \mathrm{L} /(\mathrm{mol} \cdot \mathrm{s})$. This result is consistent with a single-site mechanism instead of a bimolecular mechanism for water oxidation. The maximum TON was 29 over $15 \mathrm{~h}$ of electrolysis, giving a Faradaic efficiency for $\mathrm{O}_{2}$ evolution of $45 \%$. Importantly, a negligible kinetic isotope effect (KIE, 1.08) was observed, suggesting that a concerted oxygen atom-proton transfer mechanism was not involved, i.e., water nucleophilic attack on the $\mathrm{Fe}^{\mathrm{V}}=\mathrm{O}$ unit probably gave the peroxide intermediate $\mathrm{Fe}^{\mathrm{III}}-\mathrm{OOH}_{2}$ rather than $\mathrm{Fe}^{\mathrm{III}}-\mathrm{OOH}$. The reaction mechanism proposed by the authors is shown in Fig. 8.

\subsection{Cobalt catalysts}

In 2011, Nocera and co-workers [101] synthesized hangman Co-corrole 22 (Fig. 9) and its $\beta$-octafluoro derivative $\mathbf{2 2}-\mathrm{F}_{8}$, and showed that they have high water oxidation activities. The TOF of 22- $\mathrm{F}_{8}$ was $0.81 \mathrm{~s}^{-1}$ in neutral phosphate buffer with an applied overpotential of $780 \mathrm{mV}$. Significantly, both complexes are much more active than the non-hangman Co complex with 5,10,15-tris(pentafluorophenyl)corrole 23 (Fig. 9) in water oxidation catalysis. A $\mathrm{Co}^{\mathrm{IV}}$-corrole ${ }^{\bullet+}$ moiety was proposed as the catalytically active species. Ertem and Cramer [102] used DFT methods to study the reaction mechanism with

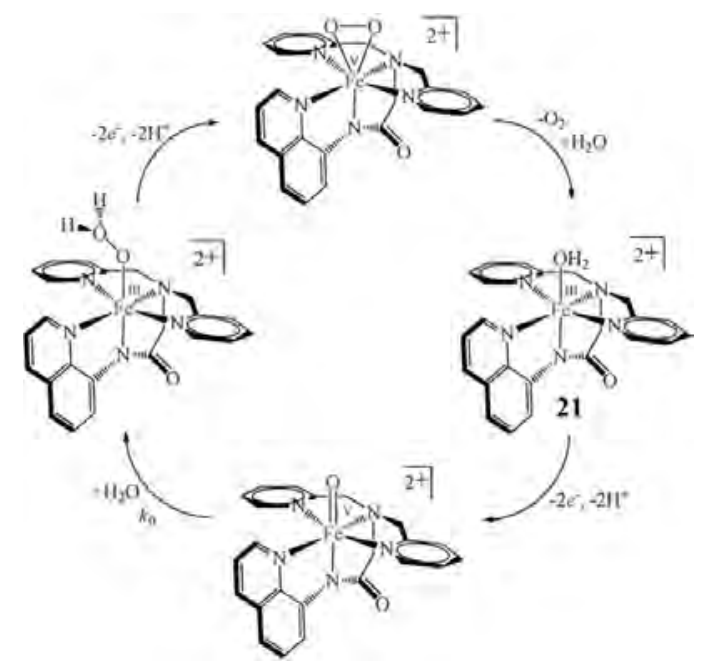

Fig. 8. A proposed water oxidation mechanism with Fe complex 21. Reprinted with permission from Ref. [100]. Copyright 2014 American Chemical Society.

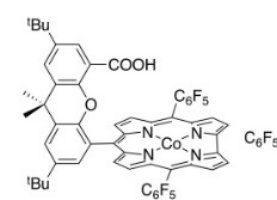

22


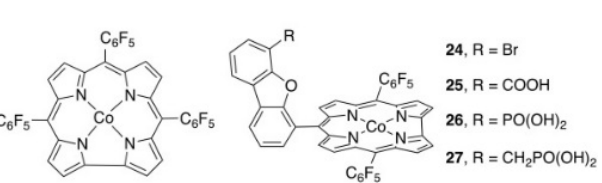

23

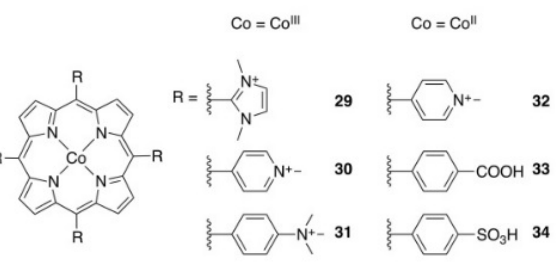

32

Fig. 9. Co-based molecular catalysts for water oxidation.

22-F8. Lai and co-workers [103] also used DFT calculations to investigate the $\mathrm{O}-\mathrm{O}$ bond formation step with $\mathbf{2 2}-\mathrm{F}_{8}$. The formally $\mathrm{Co}^{\mathrm{V}}$ species has a $\mathrm{Co}^{\mathrm{IV}}-$ corrole ${ }^{++}$character and is responsible for $0-0$ bond formation with $22-F_{8}$. It was proposed that the pendant carboxyl group serves as an intramolecular base and accepts a proton during water nucleophilic attack on the Co-oxo unit. High-valent Co-oxo units are highly active and their isolation and characterization are challenging. However, Nam and co-workers [104] successfully prepared a stable terminal $\mathrm{Co}^{\mathrm{IV}}=0$ complex. Although these authors did not observe catalytic activity of this $\mathrm{Co}^{\mathrm{IV}}=0$ complex in water oxidation, this work provided experimental evidence for the generation of $\mathrm{Co}^{\mathrm{IV}}=\mathrm{O}$ under conditions relevant to water oxidation catalysis.

Cao and co-workers [105] investigated the water oxidation reaction with Co-corrole $\mathbf{2 3}$ in detail. The cyclic voltammogram of an indium tin oxide (ITO) electrode surface-loaded with complex 23 showed a pronounced catalytic wave with an onset potential of $1.15 \mathrm{~V}$ (vs Ag/AgCl) in phosphate buffer $(0.1 \mathrm{~mol} / \mathrm{L}$; $\mathrm{pH}=7.0$ ). This wave is caused by water oxidation, as shown by the generation of numerous gas bubbles on the ITO electrode surface. The onset overpotential for water oxidation with 23 was $530 \mathrm{mV}$. The stability of $\mathbf{2 3}$ as a WOC was investigated. All the results indicated that $\mathbf{2 3}$ was stable and acted as a real molecular catalyst in water oxidation. A TOF of $0.20 \mathrm{~s}^{-1}$ was obtained at an applied potential of $1.40 \mathrm{~V}$ (vs $\mathrm{Ag} / \mathrm{AgCl}$ ). In contrast, the $\mathrm{Mn}^{\mathrm{III}}$ analog of $\mathbf{2 3}$ showed much weaker catalytic activity and decomposed during electrocatalysis in neutral phosphate buffer.

On the basis of the experimental and theoretical results, a catalytic cycle with $\mathbf{2 3}$ was proposed (Fig. 10). Starting from Co ${ }^{\mathrm{III}}$-corrole [Cor-Co ${ }^{\mathrm{III}}-\mathrm{OH}_{2}$ ], two sequential $1 \mathrm{H}^{+} / 1 \mathrm{e}^{-}$oxidation steps lead to [Cor $\left.{ }^{*+}-\mathrm{Co}{ }^{\mathrm{III}}-\mathrm{OH}\right]$ and $\left[\mathrm{Cor}^{{ }^{++}-\mathrm{Co}^{\mathrm{III}}-\mathrm{O}^{-}-}\right.$, respectively. The latter species undergoes water nucleophilic attack to 


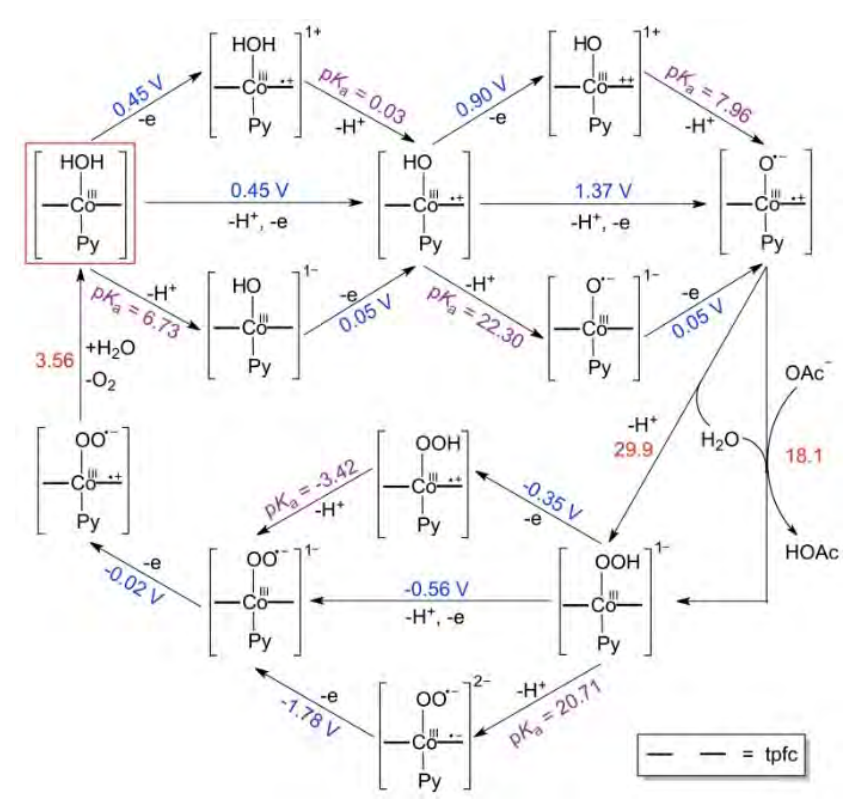

Fig. 10. A proposed water oxidation mechanism with Co corrole 23. Reprinted with permission from Ref. [105]. Copyright 2014 Royal Society of Chemistry.

produce [Cor-CoIII-OOH] ${ }^{-}$. The calculated activation energy barrier is $29.9 \mathrm{kcal} / \mathrm{mol}$ with a cluster of four water molecules acting as the proton acceptor, but it is $18.1 \mathrm{kcal} / \mathrm{mol}$ with an acetate anion acting as the proton acceptor. The transition states of these two pathways are shown in Fig. 11. Two $1 \mathrm{H}^{+} / 1 \mathrm{e}^{-}$ PCET steps then give [Cor-Co $\left.{ }^{\mathrm{III}}-\mathrm{OO}^{*-}\right]^{-}$and [Cor ${ }^{*+}-\mathrm{Co}^{\mathrm{III}}-\mathrm{OO}{ }^{\bullet-}$ ]. The resulting [Cor ${ }^{\bullet+}-\mathrm{Co}^{\mathrm{III}}-\mathrm{OO}{ }^{-}$] can release $\mathrm{O}_{2}$ by displacement with a water molecule. This process has a low energy barrier of $3.6 \mathrm{kcal} / \mathrm{mol}$. The $\mathrm{O}-\mathrm{O}$ bond formation step is therefore the rate-determining step in the catalytic cycle.

In this mechanism, there is a Co-bound pyridine molecule located at the trans position of the Co-oxo unit. The electronic effects of certain ligands can significantly affect the stability and reactivity of their trans ligands. Because the $0-0$ bond formation step is usually the rate-determining step in water oxidation, it is interesting to study the trans ligand effect in water oxidation; such studies have rarely been reported in the literature. Co-corroles are ideal for studying the trans effect because the corrole ligand can provide a stable and rigid square-planar environment for Co with two axial sites trans to each other. Recently, Cao and co-workers [106] synthesized a series of (a)



(b)

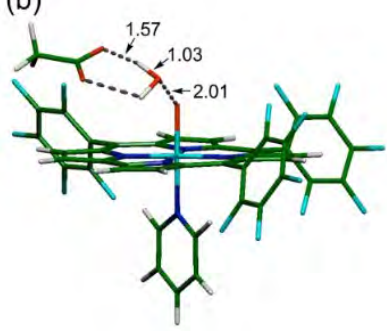

Fig. 11. Water nucleophilic attack transition state structure with Co corrole 23. (a) [Cor++-Colli-O--] with four water molecules and (b)

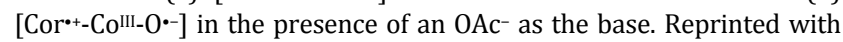
permission from Ref. [105]. Copyright 2014 Royal Society of Chemistry.
Co-corroles 23 with various axial ligands and examined their catalytic activities in water oxidation. These Co-corroles all showed two oxidation events in acetonitrile, and the oxidation waves shifted in the cathodic direction when electron-donating axial ligands were present. This trend is consistent with increased electron densities on the Co ions. When these Co-corroles were loaded on fluorine-doped tin oxide (FTO) electrodes, they were all active in electrocatalytic water oxidation, with large catalytic waves, in phosphate buffer solutions $(0.1 \mathrm{~mol} / \mathrm{L} ; \mathrm{pH}=7.0)$. Importantly, Co-corroles containing electron-donating trans axial ligands were more active. Depending on the electron-donating ability of the trans axial ligands, the onset overpotentials are in the range $510-580 \mathrm{mV}$, and the catalytic currents at $1.68 \mathrm{~V}$ (vs NHE) range from 0.78 to $1.95 \mathrm{~mA} / \mathrm{cm}^{2}$. Possible reasons for the enhanced catalytic activity with electron-donating trans axial ligands are as follows. The strong trans effect can weaken the $\mathrm{Co}^{\mathrm{V}}=\mathrm{O}$ bond and thus decrease the activation energy barrier for $\mathrm{O}-\mathrm{O}$ bond formation via water nucleophilic attack on the $\mathrm{Co}^{\mathrm{V}}-\mathrm{O}$ unit. These results show that the trans axial ligands on Co centers can considerably affect the water oxidation activities of Co-corroles.

To further study the hangman effect, Cao and co-workers [107] synthesized a series of Co-corroles with different acid/base pendants 24-27 (Fig. 9) and examined their water oxidation activities in neutral aqueous solutions. The synthesis of these Co-corroles is shown in Fig. 12. The aim of introducing different pendant groups, including $-\mathrm{Br},-\mathrm{COOH},-\mathrm{PO}(\mathrm{OH})_{2}$, and $-\mathrm{CH}_{2} \mathrm{PO}(\mathrm{OH})_{2}$, at the 6-position of the dibenzofuran unit, was to increase the proton-accepting ability of the intramolecular base groups, and consequently to enhance the water oxidation performance by assisting the $\mathrm{O}-\mathrm{O}$ bond formation step. Electrochemical measurements with catalyst-coated FTO working electrodes in phosphate buffers $(0.1 \mathrm{~mol} / \mathrm{L} ; \mathrm{pH}=7.0)$ showed that the order of the water oxidation activities was $27>26>$ $25>24$. Importantly, a plot of potential (measured at 0.52 $\mathrm{mA} / \mathrm{cm}$ ) vs $\mathrm{p} K$ a of the appended group (for $-\mathrm{PO}(\mathrm{OH})_{2}$ and $-\mathrm{CH}_{2} \mathrm{PO}(\mathrm{OH})_{2}, \mathrm{p} K_{\mathrm{a} 2}$ values were used) showed a linear relationship, with a slope of $-55 \mathrm{mV}$ per $\mathrm{p} K_{\mathrm{a}}$ unit. This result indicates that the water oxidation mechanism involves a rate-determining PCET step (i.e., 0-0 bond formation), in which the electron-transfer process becomes more favored when proton transfer is facilitated by a strong basic group.

In 2016, Cao and co-workers [108] reported enhanced water oxidation activity of a pyrene-modified Co-corrole 28 (Fig. 9). A Co complex with 5,15-bis(pentafluorophenyl)-10-(4)(1-pyrenyl)phenylcorrole (28), bearing a pyrene substituent, was synthesized (Fig. 13). When $\mathbf{2 3}$ and $\mathbf{2 8}$ were immobilized on multiwalled carbon nanotubes (MWCNTs), the 28/MWCNT composite outperformed the 23/MWCNT composite, indicating that the pyrene substituent has a significant role in electrocatalysis. The strong non-covalent $\pi-\pi$ interactions between the pyrene moiety and MWCNTs enhance the catalytic performance by facilitating fast electron transfer from the electrode to the molecular catalyst and also by increasing adhesion of the molecular catalyst to the carbon support. The presence of strong non-covalent $\pi-\pi$ interactions between the pyrene moiety and MWCNTs is supported by spectroscopic data. For ex- 

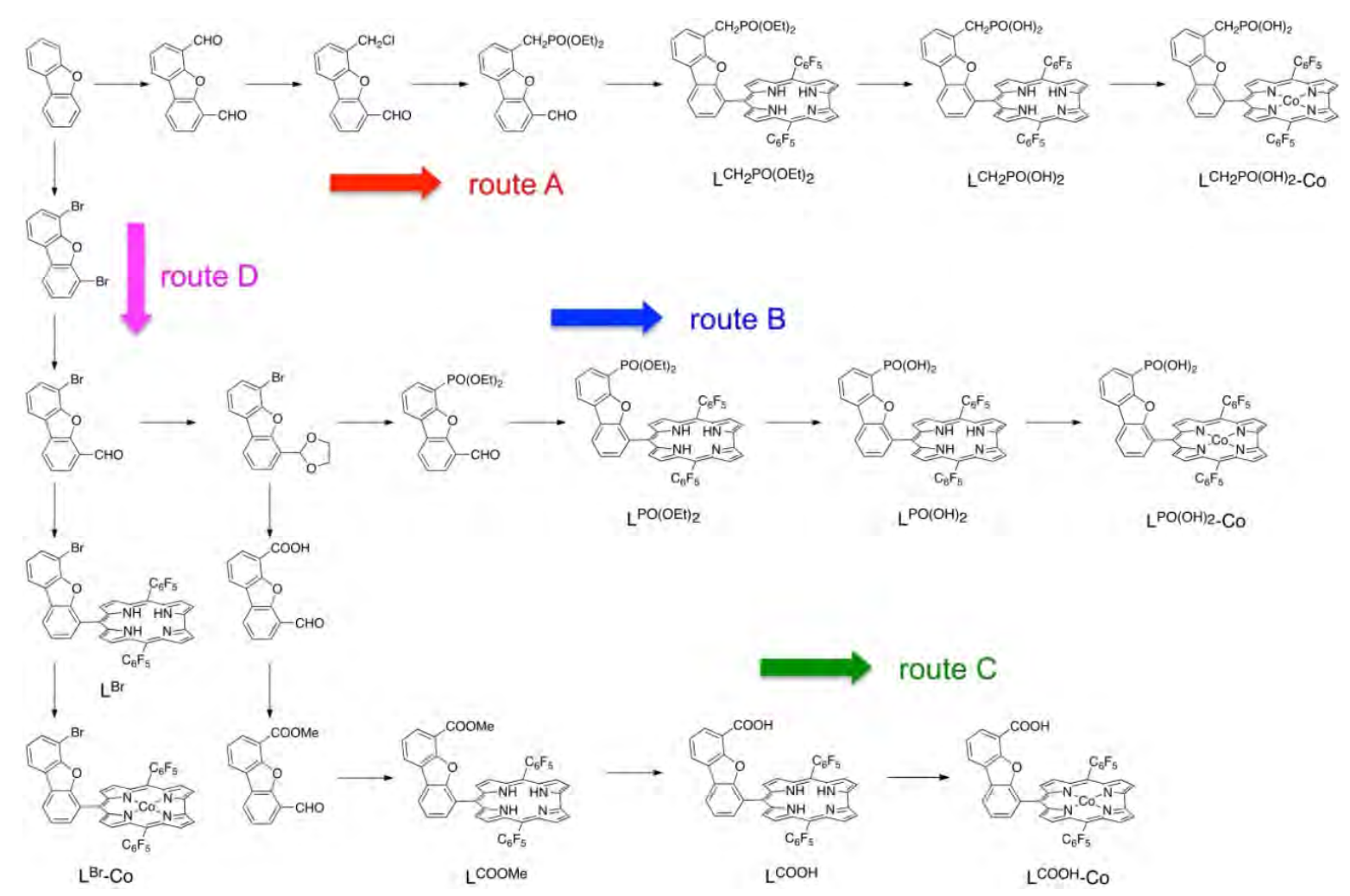

route $\mathrm{C}$

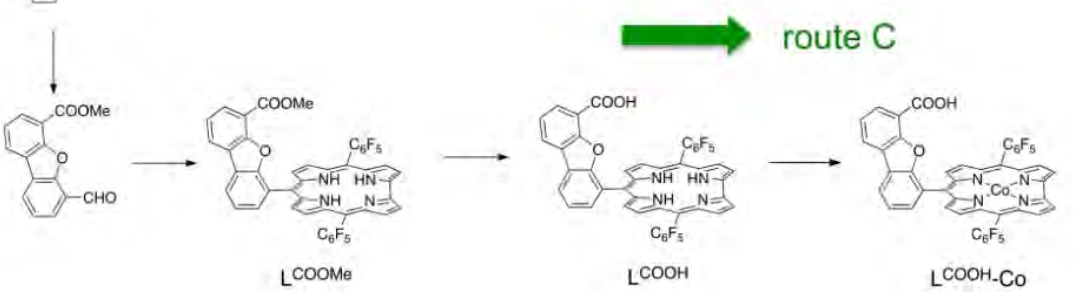

Fig. 12. Synthetic routes of Co corrole complexes 24-27. Reprinted with permission from Ref. [107]. Copyright 2017 Royal Society of Chemistry.

ample, the electronic absorption spectra of $\mathbf{2 8}$ and the 28/MWCNT composite were recorded and compared. The absorption bands at 346 and $381 \mathrm{~nm}$ in the spectrum of complex 28 blue-shifted to 334 and $372 \mathrm{~nm}$ in the 28/MWCNT composite spectrum. This indicates strong interactions between molecules of $\mathbf{2 8}$ and the MWCNT support. The 28/MWCNT composite is also much more efficient than the 23/MWCNT composite in catalyzing oxygen reduction to water $[108,109]$. Non-covalent immobilization of molecular catalysts on carbon supports
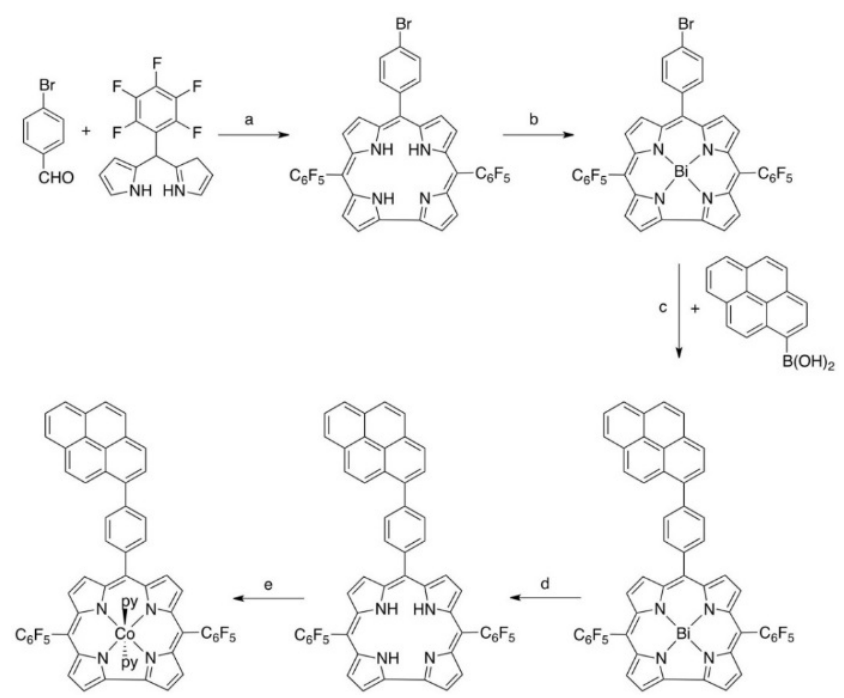

Fig. 13. Synthetic routes of Co corrole complex 28. (a) $1 . \mathrm{HCl}$, $\mathrm{MeOH} / \mathrm{H}_{2} \mathrm{O}$; 2. DDQ, $\mathrm{CHCl}_{3}$. (b) $\mathrm{BiCl}_{3}, \mathrm{NaOAc}$, THF. (c) $\mathrm{Pd}(\mathrm{OAc})_{2}, \mathrm{~K}_{3} \mathrm{PO}_{4}$, SPhos, THF $/ \mathrm{H}_{2} \mathrm{O}$. (d) $\mathrm{HCl}$, THF. (e) $\mathrm{Co}(\mathrm{OAc})_{2}$, pyridine. Reprinted with permission from Ref. [108]. Copyright 2016 American Chemical Society. through strong $\pi-\pi$ interactions is therefore a simple and straightforward method for the fabrication of hybrid catalyst-carbon materials for efficient electrocatalysis.

Co-porphyrins are another class of Co-based complexes that have been studied as molecular WOCs. Du and co-workers [110] deposited Co-tetraphenylporphyrin or Co-tetrakis(4bromophenyl)porphyrin on FTO electrodes for electrocatalytic water oxidation. These catalyst films showed good activities in borate buffer solutions $(0.5 \mathrm{~mol} / \mathrm{L} ; \mathrm{pH}=9.2)$, with onset overpotentials of 530 and $580 \mathrm{mV}$, respectively. The molecular nature of these Co-based WOCs was confirmed. TOF values of 0.50 $\mathrm{s}^{-1}$ for Co-tetraphenylporphyrin and $0.40 \mathrm{~s}^{-1}$ for Co- tetrakis(4bromophenyl)porphyrin were obtained in controlled potential electrolysis at an applied potential of $1.3 \mathrm{~V}$ ( $\mathrm{vs} \mathrm{Ag} / \mathrm{AgCl}$ ).

In 2013, Groves and Wang [111] reported electrocatalytic water oxidation with cationic water-soluble $\mathrm{Co}^{\mathrm{III}}$-porphyrins (29-31, Fig. 9) in neutral phosphate buffer solutions. The order of the activities of these catalysts was $29>30>31$. Complex 29 gave a TOF of $1.4 \times 10^{3} \mathrm{~s}^{-1}$ and a Faradaic efficiency of $90 \%$. An inhibitory effect was observed at high phosphate concentrations (i.e., >60 mmol/L). It was suggested that at low phosphate concentrations, phosphate anions can facilitate $\mathrm{O}-\mathrm{O}$ bond formation by acting as a base and accepting the proton of the nucleophilic attacking water molecule. However, at high phosphate concentrations, phosphate anions can bind to the Co center and block the binding and activation of water on Co. The onset potentials at $\mathrm{pH}=7$ decrease linearly in buffers with more basic anions, with a slope of $-54 \mathrm{mV}$ per $\mathrm{p} K_{\mathrm{a}}$ unit. This result is similar to that reported by Cao and co-workers [107], mentioned above. 
In 2013, Sakai and co-workers [112] reported photocatalytic water oxidation with three water-soluble $\mathrm{Co}^{\mathrm{II}}$-porphyrins (32-34, Fig. 9). Typically, Co-porphyrins were used as the catalyst, $\left[\mathrm{Ru}(\mathrm{bpy})_{3}\right]^{2+}$ was used as the photosensitizer, and $\mathrm{Na}_{2} \mathrm{~S}_{2} \mathrm{O}_{8}$ was used as the sacrificial oxidant. Under the optimum conditions, the TOF for $\mathrm{O}_{2}$ evolution at $\mathrm{pH}=11$ was $0.138 \mathrm{~s}^{-1}$ for 32, $0.118 \mathrm{~s}^{-1}$ for 33 , and $0.170 \mathrm{~s}^{-1}$ for 34 . Kinetic studies showed a second-order dependence of the initial reaction rate on the catalyst concentration; the reaction mechanism shown in Fig. 14 was proposed. However, these Co-porphyrin catalysts decomposed to less active (or inactive) species during catalysis. The decomposition of Co-porphyrins is probably caused by generation of singlet dioxygen $\left({ }^{1} \mathrm{O}_{2}\right)$ under photocatalytic conditions; this was confirmed by using 9,10-diphenylanthracene as a chemical probe. Highly active ${ }^{1} \mathrm{O}_{2}$ is a strong oxidant and rapidly reacts with organic substrates. Sakai and co-workers [113] used a new fluorinated Co-porphyrin 35 (Fig. 9) to improve the stability of Co-porphyrin catalysts. These bulky meso substituents were used to increase the tolerance of 35 to ${ }^{1} \mathrm{O}_{2}$ attack through steric shielding. Photocatalytic studies showed that $\mathbf{3 5}$ was more efficient than $\mathbf{3 4}$ in catalyzing water oxidation: the TON with $\mathbf{3 5}$ was approximately twice that with 34. Kinetic studies indicated that the rate-determining step in water oxidation with $\mathbf{3 5}$ was water nucleophilic attack on the Co-oxo species.

Several Co complexes with Py5-based ligands have been reported as active WOCs [114-117]. In 2011, Berlinguette and co-workers [114] prepared a mononuclear Co complex with a Py5-OMe ligand (Fig. 15) and showed that it catalyzed water oxidation in phosphate buffer $(0.1 \mathrm{~mol} / \mathrm{L} ; \mathrm{pH}=9.2)$. The attack of $\mathrm{Co}^{\mathrm{IV}}$-hydroxyl/oxo units by a water/hydroxide substrate was proposed to lead to $\mathrm{O}-\mathrm{O}$ bond formation. In a subsequent study, these authors further confirmed the molecular nature of this Co-based WOC [115]. In 2015, Thapper and co-workers [116] reported a mononuclear Co complex with a Py5-OH ligand (Fig. 15), which was a homogeneous molecular catalyst for photochemical, electrochemical, and chemical water oxidation. Unlike the Py5-OMe ligand, which contains two methoxy groups, the Py5-OH ligand contains two free hydroxyl groups. The overpotentials for water oxidation were 540 and $510 \mathrm{mV}$ at $\mathrm{pH}=8$ and 9 , respectively. Importantly, it was suggested that a Co-bound chloride ligand was critical for this cat-

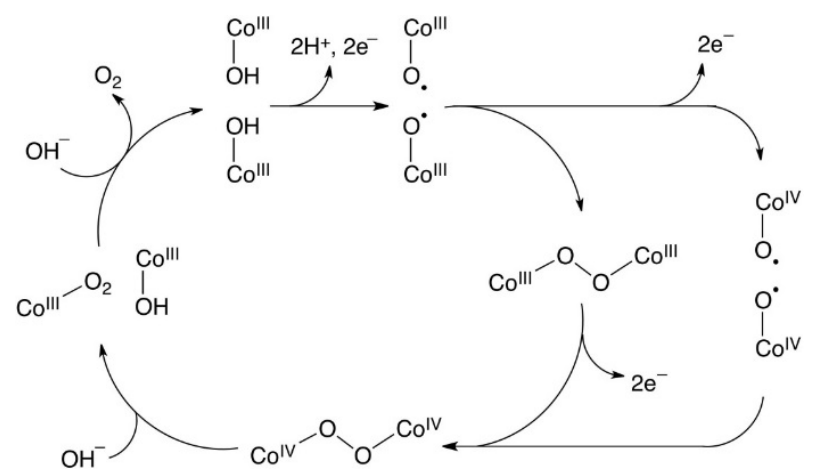

Fig. 14. Proposed $0-0$ bond formation pathways with Co porphyrins 32-34. Redrawn with permission from Ref. [112]. Copyright 2013 Royal Society of Chemistry.

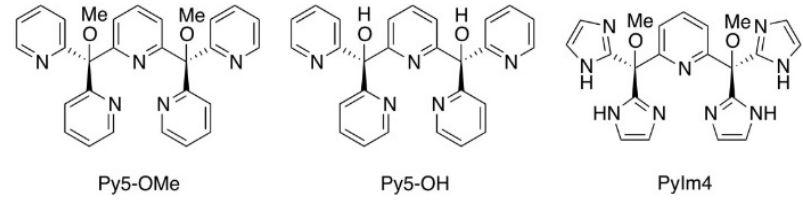

Fig. 15. Py5-based ligands.

alytic reaction because it prevented the formation of a dinuclear Co species. Siewert et al. [117] also reported a Co complex with a PyIm4 ligand (Fig. 15) as a molecular catalyst for electrochemical water oxidation. Instead of four pyridine groups, four imidazole groups were attached to the central pyridine unit. The NH moieties in the imidazole groups are thought to act as intramolecular bases for coupling multiple proton and electron transfer steps. The cyclic voltammogram of the Co complex showed a catalytic wave with an onset potential of $1.20 \mathrm{~V}$ (vs NHE) in $\mathrm{pH}=12.8$ aqueous solution, corresponding to an onset overpotential of $730 \mathrm{mV}$.

In 2015, Ding and co-workers [118] reported the mononuclear Co complex 36 (Fig. 9) as a catalyst for visible-light-driven water oxidation. When a typical three-component system with complex $\mathbf{3 6}$ as the catalyst, [Ru(bpy) $\left.]_{3}\right]^{2+}$ as the photosensitizer, and $\mathrm{Na}_{2} \mathrm{~S}_{2} \mathrm{O}_{8}$ as the oxidant was used, the maximum TON for $\mathrm{O}_{2}$ evolution was 1610. Verpoort and co-workers [119] reported another mononuclear Co complex, i.e., 37 (Fig. 9), as a catalyst for both electrochemical and photochemical water oxidation. In electrochemical studies, the catalytic water oxidation wave increased during CV scans, indicating that $\mathbf{3 7}$ was converted to another more active form. The current crossover observed in the first $\mathrm{CV}$ cycle indicated catalyst film deposition. However, characterization of this film suggested that the film was a molecular Co species rather than cobalt oxide/hydroxide. In light-driven water oxidation, a TON of 90 was obtained in $1 \mathrm{~h}$ of irradiation. A reaction mechanism based on DFT calculations was proposed.

In 2014, Ding and co-workers [120] reported a mononuclear Co-substituted silicotungstate as a catalyst for visible-lightinduced water oxidation. All-inorganic silicotungstate ligands are robust in oxidizing environments [121]. The cyclic voltammogram of this Co-substituted silicotungstate showed an oxidation peak assigned to $\mathrm{Co}$ III/CoII, at $0.82 \mathrm{~V}$ (vs $\mathrm{Ag} / \mathrm{AgCl}$ ), and a catalytic wave with an onset potential of $0.96 \mathrm{~V}$ (vs $\mathrm{Ag} / \mathrm{AgCl})$ in borate buffer solution $(\mathrm{pH}=9.0)$. This result indicates that this Co complex is active in water oxidation. In photocatalytic studies, a TON of 313, TOF of $3.2 \mathrm{~s}^{-1}$, and quantum yield of $27 \%$ for $\mathrm{O}_{2}$ evolution were obtained in solutions $\mathrm{pH}=$ 9.0) under the optimum conditions. Several lines of evidence from experimental and control studies suggested that this Co-substituted silicotungstate, rather than its decomposition product, was the real molecular catalyst.

\subsection{Nickel catalysts}

In 2015, Cao and co-workers [122] reported the first $\mathrm{Ni}$-porphyrin catalyst for water oxidation. A cationic water-soluble $\mathrm{Ni}^{\mathrm{II}}$ complex with meso-tetrakis(4- $\mathrm{N}$-methylpyridyl) porphyrin 38 (Fig. 16) was investigated as a homogeneous 
WOC. The cyclic voltammogram of $\mathbf{3 8}$ showed a large catalytic wave with an onset potential of $1.0 \mathrm{~V}$ (vs NHE) in neutral phosphate buffer $(0.10 \mathrm{~mol} / \mathrm{L})$. This value is much lower than that for the Co-porphyrin analog $\mathbf{3 0}$ (Fig. 9). The normalized cyclic voltammograms $\left(i / v_{1 / 2}, i=\right.$ current and $v=$ scan rate $)$ showed that the catalytic current decreased with increasing scan rate. This result suggests a catalytic process with a chemical rate-determining step. In water oxidation, this chemical rate-determining step is probably $\mathrm{O}-\mathrm{O}$ bond formation. The $\mathrm{KIE}$ value of $1.55\left(\mathrm{KIE}=k_{\mathrm{cat}, \mathrm{H} 2 \mathrm{O}} / k_{\mathrm{cat}, \mathrm{D} 2 \mathrm{O}}=\left(i_{\mathrm{cat}, \mathrm{H} 2 \mathrm{O}} / i_{\mathrm{cat}, \mathrm{D} 2 \mathrm{O}}\right)^{2}\right)$ supports the suggestion that the $0-0$ bond formation step is the rate-determining step in the catalytic cycle. The molecular nature of $\mathbf{3 6}$ in water oxidation was carefully investigated, and a TOF of $0.67 \mathrm{~s}^{-1}$ was determined.

Experimental and theoretical mechanistic studies suggested that the two-electron-oxidized species formed from $\mathbf{3 8}$ was the catalytically active species, and a reaction mechanism was proposed for water oxidation (Fig. 17). Two-electron oxidation gives Por-NiII-O', which reacts with a water molecule via nucleophilic attack of water on the oxo unit. This $0-0$ bond formation step is the rate-determining step and has a calculated activation energy barrier of $24.9 \mathrm{kcal} / \mathrm{mol}$ when a cluster of four water molecules accepts the proton, or $18.0 \mathrm{kcal} / \mathrm{mol}$ when an acetate anion is the proton acceptor. The transition-state structures (Fig. 18) show an increased $0-0$ bond length ( 2.15 vs $1.96 \AA, 1 \AA=0.1 \mathrm{~nm}$ ). This change indicates that the transition state with an acetate anion as the proton acceptor is formed at an earlier stage than the transition state with four water molecules acting as the proton acceptor.

$\mathrm{Lu}$ and co-workers [123] reported that the macrocyclic $\mathrm{Ni}$ complex 39 (Fig. 16) acted as a WOC. The cyclic voltammogram of 39 showed an irreversible $\mathrm{Ni}{ }^{\mathrm{III}} / \mathrm{Ni}^{\mathrm{II}}$ oxidation wave at $0.87 \mathrm{~V}$ (vs NHE) and a large catalytic wave at $1.41 \mathrm{~V}$ (vs NHE) in phosphate buffer $(0.1 \mathrm{~mol} / \mathrm{L} ; \mathrm{pH}=7.0)$. Both waves had linear $\mathrm{pH}$ dependence, with slopes of $-59 \mathrm{mV}$ per $\mathrm{pH}$ unit. The two-electron-oxidized form is therefore probably the catalytically active species in water oxidation. During controlled potential electrolysis at $1.55 \mathrm{~V}$ (vs NHE), the current increased gradually from 0.15 to $0.90 \mathrm{~mA} / \mathrm{cm}^{2}$ in the first hour, without stirring, and then stabilized at ca. $0.9 \mathrm{~mA} / \mathrm{cm}^{2}$ during further electrolysis. The authors proposed that a new active species was generated during electrolysis. Theoretical studies suggested that the Ni complex with two trans vacant sites was
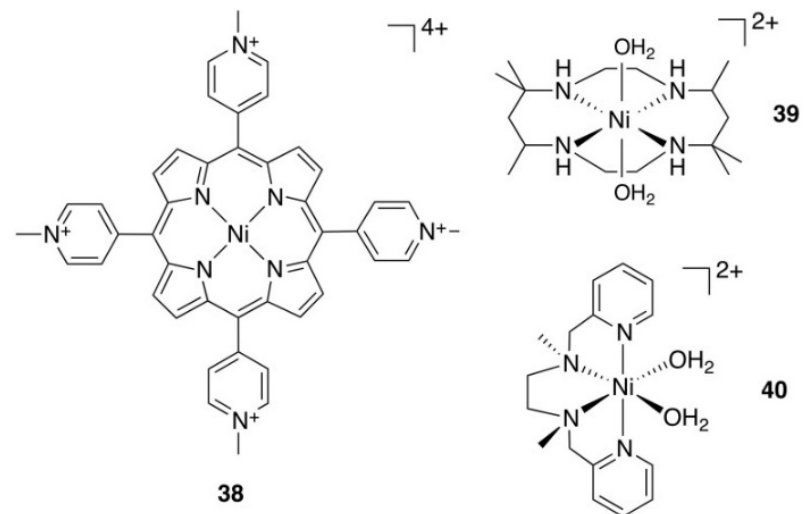

Fig. 16. Ni-based molecular catalysts for water oxidation.

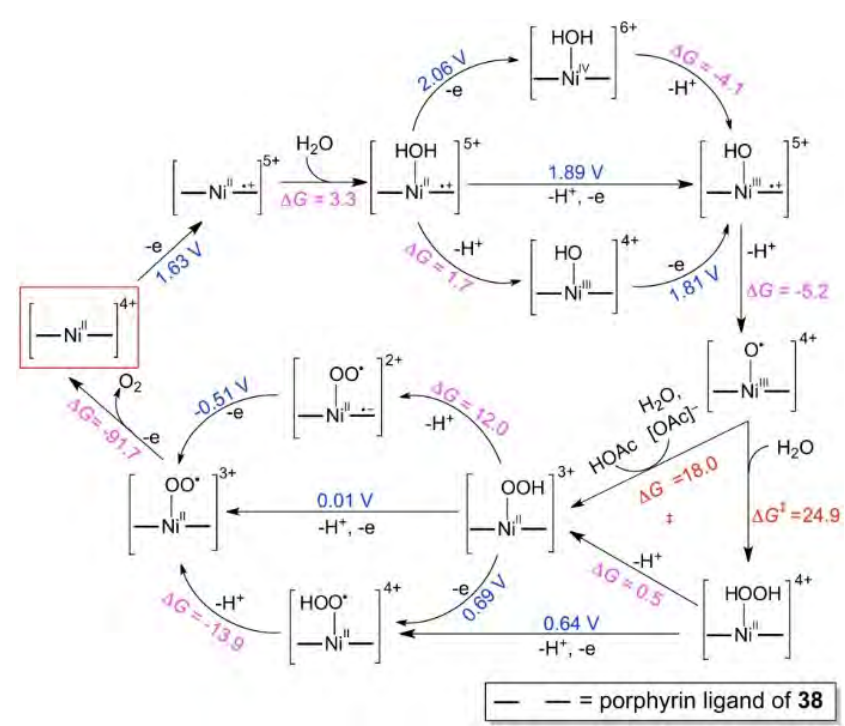

Fig. 17. A proposed water oxidation mechanism with Ni porphyrin 38 Redrawn with permission from Ref. [122]. Copyright 2015 American Chemical Society.
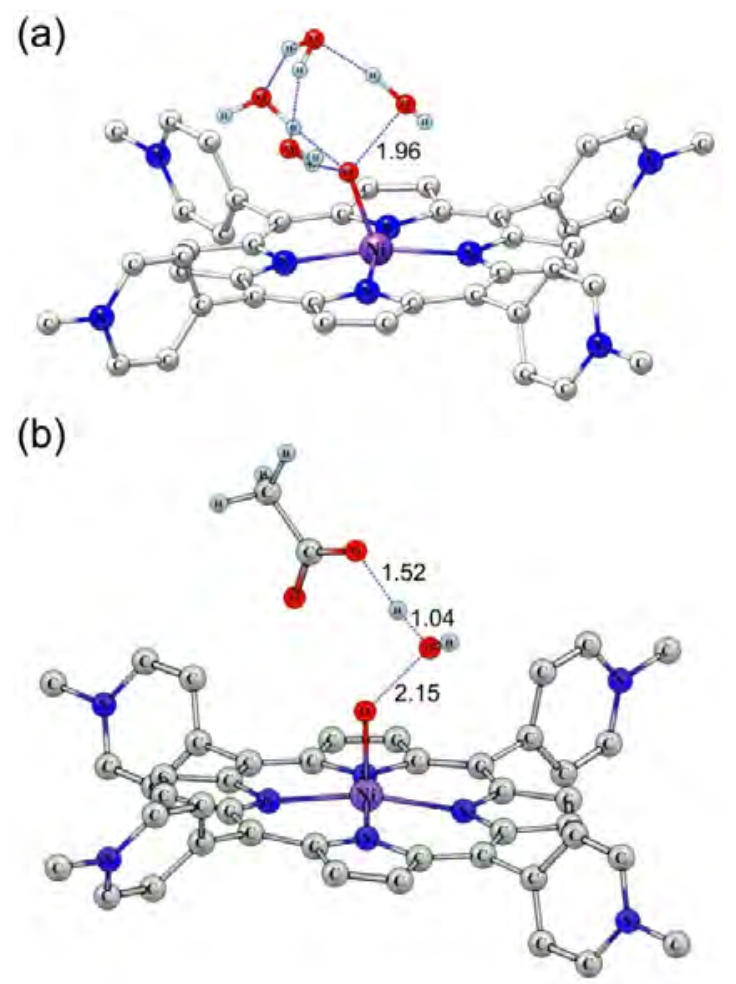

Fig. 18. Transition state structure of $0-0$ bond formation step via water nucleophilic attack. (a) [Por-NiIII-O $]^{4+}$ with four water molecules and (b) [Por-NiIII-O- $]^{4+}$ in the presence of one water molecule and one $\mathrm{OAc}^{-}$anion. Reprinted from Ref. [122]. Copyright 2015 American Chemical Society.

slowly converted to the cis isomer, and the $0-0$ bond was formed through $\mathrm{HO}-\mathrm{OH}$ coupling on the $\mathrm{Ni}$ ion. $\mathrm{Lu}$ and co-workers [124] subsequently reported $\mathrm{Ni}$ complex $\mathbf{4 0}$ (Fig. 16), containing two cis vacant sites, for water oxidation. DFT calculations suggested that the coupling of two hydroxyl groups on the formally $\mathrm{Ni}^{\mathrm{IV}}$ ion of complex $\mathbf{4 0}$ was possible. This intramolecular $\mathrm{O}-\mathrm{O}$ bond formation had a calculated acti- 
vation energy barrier of $18.9 \mathrm{kcal} / \mathrm{mol}$. These authors also reported that an analog of complex 40, which contained two cis vacant sites, was an active WOC [125]. A similar 0-0 bond formation mechanism, with a $7.9 \mathrm{kcal} / \mathrm{mol}$ activation energy barrier, was proposed.

In 2016, Nath and co-workers [126] reported a selenide-coordinated Ni complex for electrocatalytic water oxidation. This selenide-coordinated Ni complex can efficiently catalyze water oxidation by reaching a current density of 10 $\mathrm{mA} / \mathrm{cm}^{2}$ at a low overpotential of $200 \mathrm{mV}$ in $\mathrm{KOH}$ solution $(1.0$ $\mathrm{mol} / \mathrm{L}$ ). This small overpotential is caused by the low electronegativity of selenide, which leads to increased covalency of the $\mathrm{Ni}$-Se bonds. As a consequence, the Ni center can be oxidized at much lower potentials to generate the catalytically active species for water oxidation. In 2016, Sun and co-workers [127] reported a water-soluble Ni-Py5 complex for electrocatalytic water oxidation. The cyclic voltammogram of this Ni-Py5 showed a $\mathrm{Ni}^{\mathrm{III}} / \mathrm{Ni}^{\mathrm{II}}$ oxidation peak at $1.41 \mathrm{~V}$ (vs NHE) in a phosphate buffer $(\mathrm{pH}=7)$. This $\mathrm{Ni}{ }^{\mathrm{III}} / \mathrm{Ni}^{\mathrm{II}}$ oxidation had a linear $\mathrm{pH}$ dependence, with a slop of $-61 \mathrm{mV}$ per $\mathrm{pH}$ unit. After this metal-based oxidation, a catalytic wave for water oxidation was observed. The molecular nature of this catalyst was confirmed, and a reaction mechanism that involved a water nucleophilic attack pathway was proposed. In this mechanism, the phosphate anions were important because they greatly enhanced water oxidation catalysis, and a rate constant of $1820 \mathrm{~L} /(\mathrm{mol} \cdot \mathrm{s})$ was achieved.

\subsection{Copper catalysts}

In 2012, Mayer and co-workers [128] reported the first example of a homogeneous $\mathrm{Cu}$ catalyst for electrochemical water oxidation. Mixing various simple $\mathrm{Cu}$ salts with bipyridine at high $\mathrm{pH}$ led to in situ formation of $\mathrm{Cu}$-bipyridine-hydroxo complex 41 (Fig. 19). The cyclic voltammogram of this $\mathrm{Cu}$ complex in aqueous solutions $(\mathrm{pH}=11.8-13.3)$ showed large and irreversible catalytic currents for $\mathrm{O}_{2}$ evolution. Electrochemical, electron paramagnetic resonance, and other studies indicated that the dominant catalytic species was a monomeric [(bpy) $\left.\mathrm{Cu}(\mathrm{OH})_{2}\right]$ moiety, rather than heterogeneous nanoparticles formed during electrocatalysis. This $\mathrm{Cu}$ complex is among the most active homogeneous WOCs, with a TOF of $100 \mathrm{~s}^{-1}$. In 2014, Lin and co-workers [129] used 6,6'-dihydroxy-2,2'-bipyridine to synthesize a similar $\mathrm{Cu}$-bipyridine-hydroxo complex, i.e., 42 (Fig. 19), for electrocatalytic water oxidation. The introduction of two pendant hydroxyl groups enabled complex 42 to catalyze water oxidation at much lower potentials than those needed by its analog 41. Experimental and computational studies suggested that this 6,6'-dihydroxy-2,2'-bipyridine ligand is redox non-innocent and participates in electron-transfer processes. This can facilitate oxidation of the $\mathrm{Cu}$ center and can provide an active WOC with a low overpotential.

In 2013, Meyer and co-workers [130] reported a $\mathrm{Cu}$ complex 43 with a self-assembled triglycylglycine macrocyclic ligand (Fig. 19), as an electrocatalyst for water oxidation in phosphate buffer $(\mathrm{pH}=11)$. The cyclic voltammogram of $\mathbf{4 3}$ showed a well-defined, reversible oxidation wave at $E_{1 / 2}=0.58$

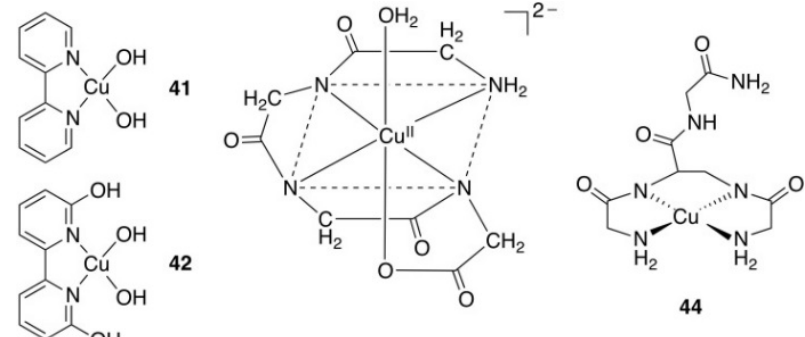

43



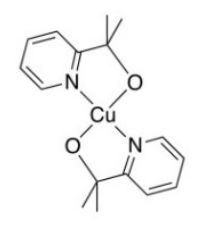

47

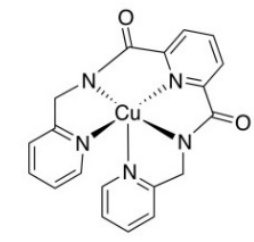

48

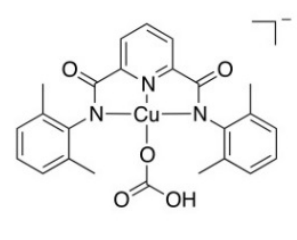

49
Fig. 19. Cu-based molecular catalysts for water oxidation.

$\mathrm{V}$ (vs NHE) and an additional, irreversible catalytic wave at $E_{\mathrm{p}, \mathrm{a}}$ $=1.32 \mathrm{~V}$ (vs NHE). The first oxidation was assigned to the $\mathrm{Cu}^{\mathrm{III}} / \mathrm{Cu}^{\mathrm{II}}$ redox couple, was $\mathrm{pH}$ dependent, and decreased at 59 $\mathrm{mV}$ per $\mathrm{pH}$ unit. The catalytic wave had an onset potential of $1.10 \mathrm{~V}$ (vs NHE), corresponding to an overpotential of $520 \mathrm{mV}$. Mechanistic studies suggested that a formally $\mathrm{Cu}^{\mathrm{IV}}$ species was the catalytically active species in water oxidation; a proposed mechanism is shown in Fig. 20. In this mechanism, the $\mathrm{Cu}^{\mathrm{IV}}=0$ intermediate reacts with a water molecule to form the $0-0$ bond; this is the rate-determining step.

In 2015, Pap and co-workers [131] reported two similar mononuclear $\mathrm{Cu}$-tetrapeptide complexes as WOCs. These $\mathrm{Cu}$ complexes, i.e., 44 and 45 (Fig. 19), were synthesized with two different l-2,3-diaminopropionic acid-based peptides, which form stable 1:1 complexes with $\mathrm{Cu}^{\mathrm{II}}$ in basic solutions. The $\mathrm{Cu}^{\mathrm{III}} / \mathrm{Cu}^{\mathrm{II}}$ redox potentials were 0.72 and $0.76 \mathrm{~V}$ (vs $\mathrm{Ag} / \mathrm{AgCl}$ ) for 44 and 45, respectively. The cyclic voltammograms of these $\mathrm{Cu}$ complexes in phosphate buffers $(\mathrm{pH}=11)$ showed electrocatalytic waves for water oxidation, with onset potentials above $1.0 \mathrm{~V}$ (vs $\mathrm{Ag} / \mathrm{AgCl}$ ). TOFs of 24 and $53 \mathrm{~s}^{-1}$ were calculated for 44 and 45 , respectively.

Llobet and co-workers [132] reported a series of $\mathrm{Cu}$ complexes with a new family of tetraanionic tetradentate amidate ligands as WOCs. The Cu complexes 46a-d (Fig. 19) were active electrocatalysts for water oxidation in basic aqueous solutions. Importantly, the overpotential for water oxidation decreased greatly, down to $170 \mathrm{mV}$, with increasing electron-donating capacity of the aromatic ring. The two-electron-oxidized form $\mathrm{L} \cdot-\mathrm{Cu}^{\mathrm{III}}-\mathrm{OH}$ was suggested as the catalytically active species in water oxidation (Fig. 21). This species reacts with an additional 


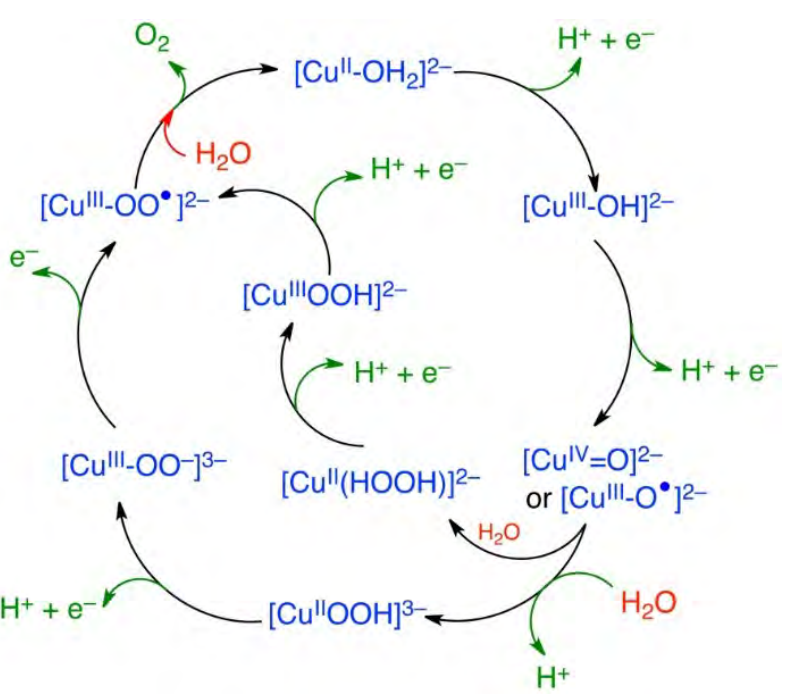

Fig. 20. A proposed water oxidation mechanism with $\mathrm{Cu}$ complex 43. Redrawn with permission from Ref. [130]. Copyright 2013 American Chemical Society.

hydroxide anion to produce a peroxo intermediate, L-CuII-(HO-OH). However, in a typical water nucleophilic attack step, the hydroxide anion directly attacks the metal-oxo unit to form the $0-0$ bond in a single step. A DFT calculation suggested that one electron from the incoming hydroxide anion transfers to the $\mathrm{L}^{-}-\mathrm{Cu}^{\mathrm{III}}-\mathrm{OH}$ moiety to form a (HO---OH) -- radical anion fragment with a partial $\mathrm{O}-\mathrm{O}$ bond. This ( $\mathrm{HO}---\mathrm{OH})^{--}$ radical anion can hydrogen bond to the $\mathrm{L}-\mathrm{Cu}^{\mathrm{III}}$ complex. Subsequent electron transfer converts the (HO---OH) -- radical anion to a singlet $\mathrm{HO}-\mathrm{OH}$ peroxo species and an $\mathrm{L}-\mathrm{Cu}^{\mathrm{II}}$ unit. These authors labeled this type of mechanism as single-electron-transfer water nucleophilic attack, which differs from the traditional two-electron-transfer step. In this mechanism, $\mathrm{O}-\mathrm{O}$ bond formation has a low activation energy barrier of $5.5 \mathrm{kcal} / \mathrm{mol}$.

In 2017, Crabtree and co-workers [133] reported electrocatalytic water oxidation by $\mathrm{Cu}$ complex 47 , which has an oxidation-resistant ligand (Fig. 19). Catalytic water oxidation with

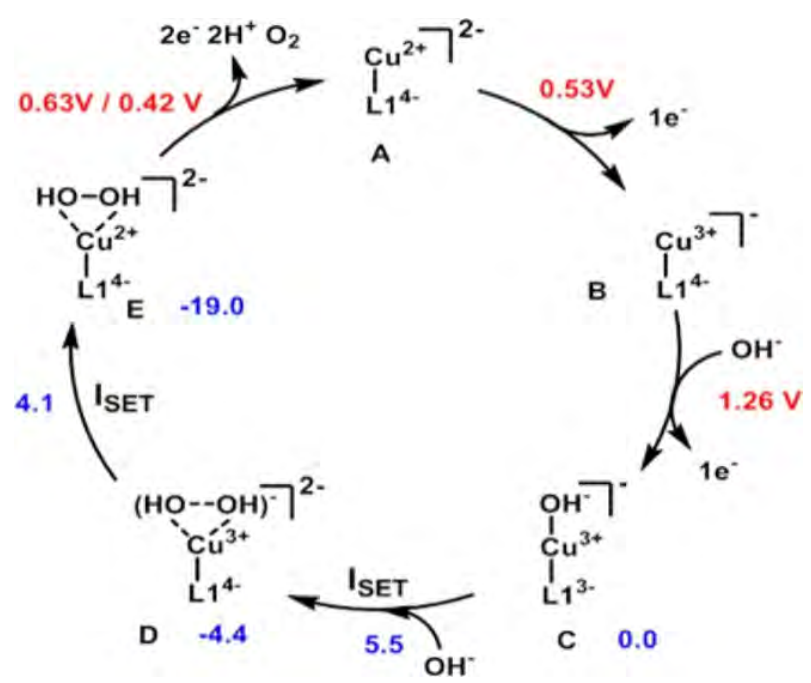

Fig. 21. A proposed water oxidation mechanism with $\mathrm{Cu}$ complex 46 a. Reprinted from Ref. [132]. Copyright 2015 American Chemical Society.
47 occurs at relatively low overpotentials of 520-580 $\mathrm{mV}$ in basic solutions, with a TOF of $0.7 \mathrm{~s}^{-1}$. In 2014, Meyer and co-workers [134] reported electrocatalytic water oxidation with $\mathrm{Cu}$ complex 48 (Fig. 19). Electrochemical kinetic studies indicated a single-site water oxidation mechanism. It was suggested that phosphate buffer anions assist electron transfer to the electrode and proton transfer to the phosphate anions, and facilitate the rate-limiting $0-0$ bond formation step through an atom-proton transfer process. The two-electron oxidized form with either a $\mathrm{d}^{7} \mathrm{Cu}^{\mathrm{IV}}-\mathrm{OH}$ or a d ${ }^{8} \mathrm{~L}^{-}-\mathrm{Cu}^{\mathrm{III}}-\mathrm{OH}$ electronic configuration reacts with a water molecule to form the $0-0$ bond, during which a phosphate anion can act as a base and assist proton transfer. In 2016, Cao and co-workers [135] reported a water-soluble $\mathrm{Cu}$ complex with tris(2-fluoro-6-pyridylmethyl)amine for both photocatalytic and electrocatalytic water oxidation. The strong binding affinity of the polypyridine ligand and its robust and oxidation-resistant features are critical for the observed activity of this $\mathrm{Cu}$ complex.

In 2017, Cao and co-workers [136] reported electrocatalytic water oxidation by a water-soluble $\mathrm{Cu}$ complex with the dianionic tridentate pincer ligand $N, N$ '-2,6-dimethylphenyl-2,6pyridinedicarboxamidate 49 (Fig. 19) in carbonate buffer solutions. This tridentate pincer ligand binds a $\mathrm{Cu}^{\mathrm{II}}$ ion through three nitrogen atoms, which define an equatorial plane. The fourth coordination site in the equatorial plane is occupied by a carbonate group, which can act as a potential proton shuttle during water activation, including steps involved in formation of the catalytically active species and subsequent $0-0$ bond formation. The cyclic voltammogram of $\mathbf{4 9}$ in carbonate buffer $(0.10 \mathrm{~mol} / \mathrm{L} ; \mathrm{pH}=10)$ showed a reversible $\mathrm{Cu}{ }^{\mathrm{III}} / \mathrm{Cu}^{\mathrm{II}}$ oxidation wave at $0.94 \mathrm{~V}$ (vs NHE) and a pronounced catalytic water oxidation wave with an onset potential of $1.29 \mathrm{~V}$ (vs NHE). Differential pulse voltammetry of $\mathbf{4 9}$ gave two oxidation waves, at $E_{\mathrm{p}, \mathrm{a}}=0.93$ and $1.51 \mathrm{~V}$ (vs NHE), in carbonate buffer ( $\mathrm{pH}=10$ ). These results indicate that the two-electron oxidized form of 49 is the catalytically active species in water oxidation.

On the basis of experimental and theoretical studies, the catalytic cycle shown in Fig. 22 was proposed. One-electron oxidation of 49 gives a $\mathrm{Cu}$ III species [ $\mathrm{L}-\mathrm{Cu}^{\mathrm{III}}-\mathrm{CO}_{3} \mathrm{H}$ ], which then binds a water molecule. Subsequent intramolecular proton transfer from the $\mathrm{Cu}$-bound water molecule to the $-\mathrm{CO}_{3} \mathrm{H}$ group, accompanied by structural rearrangement, generates $\left[\mathrm{L}-\mathrm{Cu}^{\mathrm{III}}\left(\mathrm{H}_{2} \mathrm{CO}_{3}\right)-\mathrm{OH}\right]$, with an activation energy barrier of 5.3 $\mathrm{kcal} / \mathrm{mol}$. In the resulting structure, the carbonic acid molecule moves to the axial position relative to the $\mathrm{Cu}$ atom, with a long $\mathrm{Cu}-0$ bond length of $2.54 \AA$ ( $1 \AA=0.1 \mathrm{~nm})$, and participates in hydrogen-bonding interactions with the Cu-bound hydroxyl group (Fig. 23(a)). After release of the carbonic acid molecule, the resulting species $\left[\mathrm{L}-\mathrm{Cu}{ }^{\text {III }}-\mathrm{OH}\right]$ undergoes a one-electron oxidation to give an oxo radical species, [ $\left.\mathrm{L}_{-} \mathrm{Cu}^{\mathrm{III}-\mathrm{O}^{-}}\right]$, which reacts with a water molecule to form the $\mathrm{O}-\mathrm{O}$ bond. This water nucleophilic attack step is assisted by a $\mathrm{Cu}$-bound $\mathrm{HCO}_{3}{ }^{-}$anion, which acts as a proton accepter. As shown in Fig. 23(b), in the transition state for $\mathrm{O}-\mathrm{O}$ bond formation, the $\mathrm{HCO}_{3}{ }^{-}$anion is weakly bound to the $\mathrm{Cu}$ atom as an axial ligand, with a $\mathrm{Cu}-\mathrm{O}$ bond distance of $2.38 \AA(1 \AA=0.1 \mathrm{~nm})$, and also hydrogen bonds to the attacking water molecule to assist this pro- 


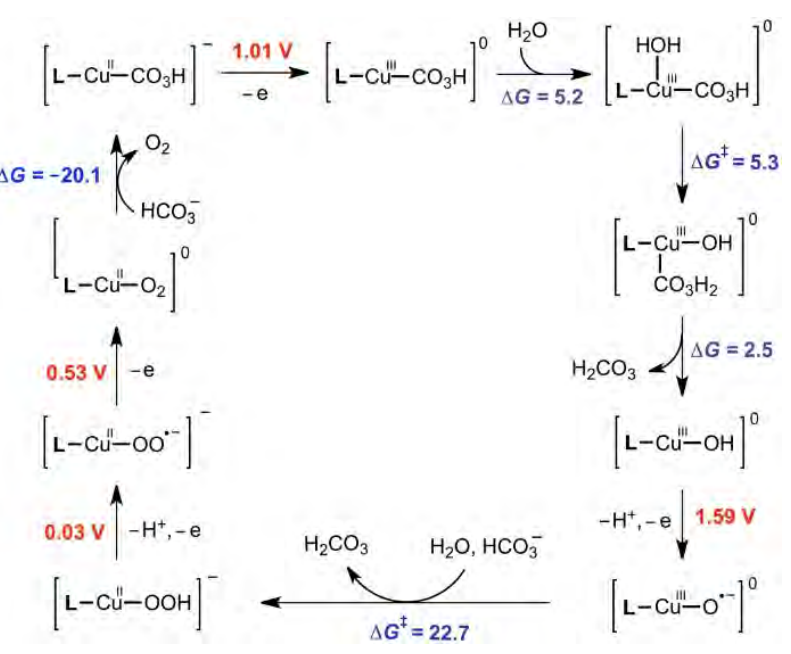

Fig. 22. A proposed water oxidation mechanism with $\mathrm{Cu}$ complex 49. Redrawn with permission from Ref. [136]. Copyright 2017 American Chemical Society.

(a)

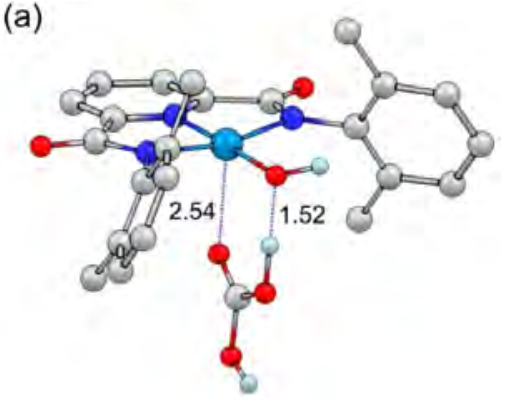

(b)

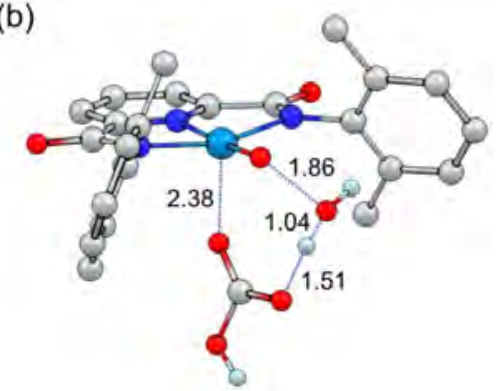

Fig. 23. Optimized structures of the intermediate and the transition state of $\mathrm{Cu}$ complex $\mathbf{4 9}$ during water oxidation, showing the proton shuttle role of the Cu-bound carbonate group. Redrawn with permission from Ref. [136]. Copyright 2017 American Chemical Society.

ton-transfer process. Computational evidence shows that the $\mathrm{Cu}$-bound carbonate group can act as an intramolecular base and assist the removal of protons for water activation, including steps involved in formation of the catalytically active species and subsequent $\mathrm{O}-\mathrm{O}$ bond formation.

\section{Concluding remarks}

This review article summarizes recent advances in the development of new and efficient WOCs based on first-row transition metals, namely $\mathrm{Mn}, \mathrm{Fe}, \mathrm{Co}, \mathrm{Ni}$, and $\mathrm{Cu}$. Considerable insights have been gained in terms of catalyst design and water oxidation mechanisms at single-metal sites. Despite these achievements, catalysts that can function at low overpotentials with high catalytic rates (i.e., catalytic currents) are still lacking. To further improve the efficiency of molecular WOCs, it is crucial to better understand the details of the reaction mechanism, in particular, the catalytically active species and the rate-determining step. Generation of the catalytically active species at low potentials is the key to decreasing the overpotentials required for water oxidation, and accelerating the rate-determining step can significantly improve the reaction rate. A better understanding of the reaction mechanism will therefore enable rational design of ligands and molecular catalysts for highly efficient water oxidation. Several ligand design strategies can be considered for lowering overpotentials and increasing reaction rates.

The following strategies can be used to lower the overpotentials for water oxidation, i.e., to generate the catalytically active species at lower potentials. (1) High-valent metal-oxo units are usually the catalytically active species. Nucleophilic attack of the metal-oxo unit by water or coupling between two metal-oxo units through a bimetallic pathway leads to $0-0$ bond formation. As a consequence, negatively charged ligands or multidentate ligands with strong $\sigma$-donating abilities are favored. (2) Redox non-innocent ligands can participate in electron transfer and therefore help to accumulate oxidizing equivalents. This feature is particularly valuable for water oxidation at single-metal sites. (3) Metal complexes containing ligands with strongly electron-donating substituents catalyze water oxidation at low overpotentials. However, the increased electron density of the ligand backbone decreases the stability of molecular catalysts. Fine-tuning of the ligand electronic structure is therefore the key to producing robust WOCs with low overpotentials. On the basis of these factors, negatively charged multidentate amidate ligands, and porphyrin and corrole ligands are excellent candidates for synthesizing WOCs that function at low overpotentials.

The following strategies can be used to improve the reaction rate, i.e., to accelerate the rate-determining step. (1) Introduced intramolecular basic groups facilitate water nucleophilic attack by accepting protons. As mentioned above, nucleophilic attack of the metal-oxo unit by water is commonly suggested as the reaction pathway in the rate-limiting $0-0$ bond formation step. During this process, one proton from the attacking water molecule is lost, with generation of a peroxo intermediate. Intramolecular basic groups can act as proton acceptors and assist this process. (2) In some cases, the $\mathrm{O}-\mathrm{O}$ bond is formed through a two-step, single-electron-transfer water nucleophilic attack instead of the traditional two-electron-transfer step. In this mechanism, it is suggested that one electron from the incoming hydroxide anion transfers to the metal-oxo/hydroxo species to form a partial $\mathrm{O}-\mathrm{O}$ bond with radical anion features; subsequent electron transfer converts the radical anion to a singlet peroxo state. DFT calculations suggest that the activation energy barriers to $0-0$ bond formation via this mechanism are low. Ligands that can stabilize the partially $\mathrm{O}-\mathrm{O}$ bonded radical anions are therefore favorable. (3) Metal complexes with two cis labile/vacant coordination sites have the potential to form the $\mathrm{O}-\mathrm{O}$ bond through $\mathrm{HO}-\mathrm{OH}$ coupling on the same metal ion. 
Ligands that can provide a pre-organized geometry that affords this coordination environment are likely to improve the water oxidation efficiency.

In addition to these factors, PCET is a fundamental aspect of water oxidation that needs to be considered. PCET can prevent charge accumulation and therefore can lower overpotentials by avoiding the generation of high-energy intermediates. The coupling of protons and electrons is therefore generally thermodynamically favored in the water oxidation reaction, although the removal/addition of protons to the reaction can impede the kinetics. Stability is another issue for molecular WOCs. Organic ligand backbones can potentially be destroyed under the harsh oxidative conditions required for water oxidation. Ligands with sufficient tolerance of oxidative decomposition are therefore mandatory, and these generally do not contain active $\mathrm{C}-\mathrm{C}$ and $\mathrm{C}-\mathrm{H}$ bonds. Although the mononuclear first-row transitionmetal complexes reported so far still cannot fulfill the requirements for large-scale water oxidation in practical applications, the results summarized here will certainly contribute to our understanding of the water oxidation process. This information is therefore valuable for achieving the ultimate goal of artificial photosynthesis through water splitting.

\section{References}

[1] W. Zhang, W. Z. Lai, R. Cao, Chem. Rev, 2017, 117, 3717-3797.

[2] T. R. Cook, D. K. Dogutan, S. Y. Reece, Y. Surendranath, T. S. Teets, D. G. Nocera, Chem. Rev., 2010, 110, 6474-6502.

[3] R. Cao, W. Z. Lai, P. W. Du, Energy Environ. Sci., 2012, 5, 8134-8157.

[4] X. Liu, P. W. Du, R. Cao, Nat. Commun., 2013, 4, 2375.

[5] J. Qi, W. Zhang, R. Cao, Adv. Energy Mater., 2017, DOI: 10.1002/aenm.201701620.

[6] D. Gust, T. A. Moore, A. L. Moore, Acc. Chem. Res., 2009, 42, 1890-1898.

[7] H. Dau, I. Zaharieva, Acc. Chem. Res., 2009, 42, 1861-1870.

[8] D. G. Nocera, Acc. Chem. Res., 2012, 45, 767-776.

[9] X. L. Li, H. T. Lei, X. J. Guo, X. L. Zhao, S. P. Ding, X. Q. Gao, W. Zhang, R. Cao, ChemSusChem, 2017, 10, 4632-4641.

[10] H. T. Lei, H. Y. Fang, Y. Z. Han, W. Z. Lai, X. F. Fu, R. Cao, ACS Catal., 2015, 5, 5145-5153.

[11] Y. Z. Han, H. Y. Fang, H. Z. Jing, H. L. Sun, H. T. Lei, W. Z. Lai, R. Cao, Angew. Chem. Int. Ed., 2016, 55, 5457-5462.

[12] X. Sala, S. Maji, R. Bofill, J. García-Antón, L. Escriche, A. Llobet, Acc. Chem. Res., 2014, 47, 504-516.
[13] M. D. Kärkäs, B. Åkermark, Dalton Trans., 2016, 45, 14421-14461.

[14] M. D. Kärkäs, O. Verho, E. V. Johnston, B. Åkermark, Chem. Rev., 2014, 114, 11863-12001.

[15] T. K. Michaelos, D. Y. Shopov, S. B. Sinha, L. S. Sharninghausen, K. J. Fisher, H. M. C. Lant, R. H. Crabtree, G. W. Brudvig, Acc. Chem. Res., 2017, 50, 952-959.

[16] J. D. Blakemore, R. H. Crabtree, G. W. Brudvig, Chem. Rev., 2015, 115, 12974-13005.

[17] Y. Z. Wu, M. X. Chen, Y. Z. Han, H. X. Luo, X. J. Su, M. T. Zhang, X. H. Lin, J. L. Sun, L. Wang, L. Deng, W. Zhang, R. Cao, Angew. Chem. Int. $E d$, 2015, 54, 4870-4875.

[18] J. Qi, W. Zhang, R. J. Xiang, K. Q. Liu, H. Y. Wang, M. X. Chen, Y. Z. Han, R. Cao, Adv. Sci., 2015, 2, 1500199.

[19] M. X. Chen, Y. Z. Wu, Y. Z. Han, X. H. Lin, J. L. Sun, W. Zhang, R. Cao, ACS Appl. Mater. Interfaces, 2015, 7, 21852-21859.

[20] W. Zhang, J. Qi, K. Q. Liu, R. Cao, Adv. Energy Mater., 2016, 6, 1502489.

[21] D. Y. Guo, J. Qi, W. Zhang, R. Cao, ChemSusChem, 2017, 10, 394-400.

[22] W. Zhang, Y. Z. Wu, J. Qi, M. X. Chen, R. Cao, Adv. Energy Mater., 2017, 7, 1602547.

[23] Z. Gao, J. Qi, M. X. Chen, W. Zhang, R. Cao, Electrochim. Acta, 2017, $224,412-418$.

[24] D. Y. Guo, F. F. Chen, W. Zhang, R. Cao, Sci. Bull., 2017, 62, 626-632.

[25] S. H. Wan, J. Qi, W. Zhang, W. N. Wang, S. K. Zhang, K. Q. Liu, H. Q. Zheng, J. L. Sun, S. Y. Wang, R. Cao, Adv. Mater., 2017, 29, 1700286.

[26] J. Qi, W. Zhang, R. Cao, Chem. Commun., 2017, 53, 9277-9280.

[27] M. X. Chen, J. Qi, D. Y. Guo, H. T. Lei, W. Zhang, R. Cao, Chem. Commun., 2017, 53, 9566-9569.

[28] J. H. Yang, D. E. Wang, H. X. Han, C. Li, Acc. Chem. Res., 2013, 46, 1900-1909.

[29] X. Wang, Q. Xu, M. R. Li, S. Shen, X. L. Wang, Y. C. Wang, Z. C. Feng, J. Y. Shi, H. X. Han, C. Li, Angew. Chem. Int. Ed., 2012, 51, 13089-13092.

[30] S. S. Chen, Y. Qi, T. Hisatomi, Q. Ding, T. Asai, Z. Li, S. S. K. Ma, F. X. Zhang, K. Domen, C. Li, Angew. Chem. Int. Ed., 2015, 54, 8498-8501.

[31] Z. L. Wang, X. Zong, Y. Y. Gao, J. F. Han, Z. Q. Xu, Z. Li, C. M. Ding, S. Y. Wang, C. Li, ACS Appl. Mater. Interfaces, 2017, 9, 30696-30702.

[32] J. Q. Guan, D. Li, R. Si, S. Miao, F. X. Zhang, C. Li, ACS Catal,, 2017, 7, 5983-5986.

[33] Z. L. Wang, J. F. Han, Z. Li, M. R. Li, H. Wang, X. Zong, C. Li, Adv. Energy Mater., 2016, 6, 1600864.

[34] T. T. Yao, R. T. Chen, J. J. Li, J. F. Han, W. Qin, H. Wang, J. Y. Shi, F. T. Fan, C. Li, J. Am. Chem. Soc., 2016, 138, 13664-13672.

[35] S. Y. Wang, Y. Y. Gao, S. Miao, T. F. Liu, L. C. Mu, R. G. Li, F. T. Fan, C.

\section{Graphical Abstract}

\section{Chin. J. Catal., 2018, 39: 228-244 doi: 10.1016/S1872-2067(17)63001-8}

\section{Mononuclear first-row transition-metal complexes as molecular catalysts for water oxidation}

Ni Wang, Haoquan Zheng, Wei Zhang, Rui Cao * Shaanxi Normal University; Renmin University of China

Recent progress made on mononuclear water oxidation catalysts of the first-row transition metal elements is summarized. Particular attention is paid to the $0-0$ bond formation step, which is critical for designing new highly efficient catalysts for water oxidation.

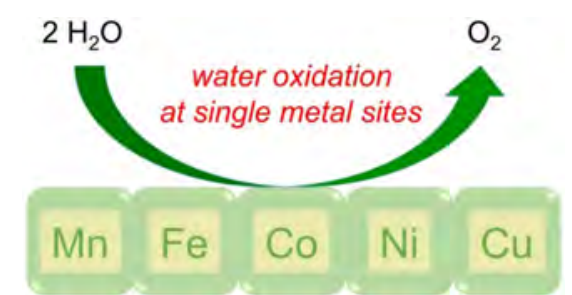


Li, J. Am. Chem. Soc., 2017, 139, 11771-11778.

[36] S. S. Chen, S. Shen, G. J. Liu, Y. Qi, F. X. Zhang, C. Li, Angew. Chem. Int. Ed., 2015, 54, 3047-3051.

[37] R. G. Li, F. X. Zhang, D. E. Wang, J. X. Yang, M. R. Li, J. Zhu, X. Zhou, H. X. Han, C. Li, Nat. Commun., 2013, 4, 1432.

[38] Y. Jiang, F. Li, F. Huang, B. B. Zhang, L. C. Sun, Chin. J. Catal., 2013, 34, 1489-1495.

[39] X. H. An, D. Shin, J. D. Ocon, J. K. Lee, Y. I. Son, J. Lee, Chin. J. Catal., 2014, 35, 891-895.

[40] Z. Liu, Y. Gao, Z. Yu, M. Zhang, J. H. Liu. Chin. J. Catal., 2015, 36, 1742-1749.

[41] C. Zhen, T. T. Wu, M. W. Kadi, I. Ismail, G. Liu, H. M. Cheng, Chin. J. Catal., 2015, 36, 2171-2177.

[42] X. Q. Du, J. W. Huang, Y. Y. Feng, Y. Ding, Chin. J. Catal., 2016, 37, 123-134.

[43] Y. B. Huang, M. Zhang, P. Liu, F. L. Cheng, L. S. Wang, Chin. J. Catal., 2016, 37, 1249-1256.

[44] L. Qian, P. F. Liu, L. Zhang, C. W. Wang, S. Yang, L. R. Zheng, A. P. Chen, H. G. Yang, Chin. J. Catal., 2017, 38, 1045-1051.

[45] X. Leng, K. H. Wu, B. J. Su, L. Y. Jang, I. R. Gentle, D. W. Wang, Chin. J. Catal., 2017, 38, 1021-1028.

[46] Y. Y. Wang, D. D. Liu, Z. J. Liu, C. Xie, J. Huo, S. Y. Wang, Chem. Commun., 2016, 52,12614-12617.

[47] L. Tao, C. Y. Lin, S. Dou, S. Feng, D. W. Chen, D. D. Liu, J. Huo, Z. H. Xia, S. Y. Wang, Nano Energy, 2017, 41, 417-425.

[48] S. Y. Wang, S. P. Jiang, Natl. Sci. Rev., 2017, 4, 163-166.

[49] Y. Z. Wu, L. Wang, M. X. Chen, Z. X. Jin, W. Zhang, R. Cao, ChemSusChem, 2017, 10, 4699-4703.

[50] D. G. H. Hetterscheid, J. N. H. Reek, Angew. Chem. Int. Ed., 2012, 51, 9740-9747.

[51] D. J. Wasylenko, R. D. Palmer, C. P. Berlinguette, Chem. Commun., 2013, 49, 218-227.

[52] J. J. Concepcion, J. W. Jurss, J. L. Templeton, T. J. Meyer, J. Am. Chem. Soc., 2008, 130, 16462-16463.

[53] D. J. Wasylenko, C. Ganesamoorthy, M. A. Henderson, B. D. Koivisto, H. D. Osthoff, C. P. Berlinguette, J. Am. Chem. Soc., 2010, 132, 16094-16106.

[54] J. J. Concepcion, M. K. Tsai, J. T. Muckerman, T. J. Meyer, J. Am. Chem. Soc., 2010, 132, 1545-1557.

[55] D. E. Polyansky, J. T. Muckerman, J. Rochford, R. F. Zong, R. P. Thummel, E. Fujita, J. Am. Chem. Soc., 2011, 133, 14649-14665.

[56] S. Roeser, P. Farràs, F. Bozoglian, M. Martínez-Belmonte, J. Benet-Buchholz, A. Llobet, ChemSusChem, 2011, 4, 197-207.

[57] H. Yamazaki, T. Hakamata, M. Komi, M. Yagi, J. Am. Chem. Soc., 2011, 133, 8846-8849.

[58] M. Murakami, D. C. Hong, T. Suenobu, S. Yamaguchi, T. Ogura, S. Fukuzumi, J. Am. Chem. Soc., 2011, 133, 11605-11613.

[59] L. P. Wang, Q. Wu, T. Van Voorhis, Inorg. Chem., 2010, 49, 4543-4553.

[60] B. Radaram, J. A. Ivie, W. M. Singh, R. M. Grudzien, J. H. Reibenspies, C. E. Webster, X. Zhao, Inorg. Chem., 2011, 50, 10564-10571.

[61] J. J. Concepcion, J. W. Jurss, M. R. Norris, Z. F. Chen, J. L. Templeton, T. J. Meyer, Inorg. Chem., 2010, 49, 1277-1279.

[62] D. J. Wasylenko, C. Ganesamoorthy, B. D. Koivisto, M. A. Henderson, C. P. Berlinguette, Inorg. Chem., 2010, 49, 2202-2209.

[63] D. J. Wasylenko, C. Ganesamoorthy, M. A. Henderson, C. P. Berlinguette, Inorg. Chem., 2011, 50, 3662-3672.

[64] L. L. Duan, Y. H. Xu, P. Zhang, M. Wang, L. C. Sun, Inorg. Chem., 2010, 49, 209-215.

[65] J. D. Blakemore, N. D. Schley, D. Balcells, J. F. Hull, G. W. Olack, C. D. Incarvito, O. Eisenstein, G. W. Brudvig, R. H. Crabtree, J. Am. Chem. Soc., 2010, 132, 16017-16029.
[66] J. F. Hull, D. Balcells, J. D. Blakemore, C. D. Incarvito, O. Eisenstein, G. W. Brudvig, R. H. Crabtree, J. Am. Chem. Soc., 2009, 131, 8730-8731.

[67] G. F. Moore, J. D. Blakemore, R. L. Milot, J. F. Hull, H. E. Song, L. Cai, C. A. Schmuttenmaer, R. H. Crabtree, G. W. Brudvig, Energy Environ. Sci., 2011, 4, 2389-2392.

[68] A. Savini, G. Bellachioma, G. Ciancaleoni, C. Zuccaccia, D. Zuccaccia, A. Macchioni, Chem, Commun., 2010, 46, 9218-9219.

[69] D. G. H. Hetterscheid, J. N. H. Reek, Chem. Commun., 2011, 47, 2712-2714.

[70] N. D. Schley, J. D. Blakemore, N. K. Subbaiyan, C. D. Incarvito, F. D'Souza, R. H. Crabtree, G. W. Brudvig, J. Am. Chem. Soc., 2011, 133, 10473-10481.

[71] K. N. Ferreira, T. M. Iverson, K. Maghlaoui, J. Barber, S. Iwata, Science, 2004, 303, 1831-1838.

[72] B. Loll, J. Kern, W. Saenger, A. Zouni, J. Biesiadka, Nature, 2005, 438, 1040-1044.

[73] Y. Umena, K. Kawakami, J. R. Shen, N. Kamiya, Nature, 2011, 473, 55-61.

[74] Y. Gao, J. H. Liu, M. Wang, Y. Na, B. Åkermark, L. C. Sun, Tetrahedron, 2007, 63, 1987-1994.

[75] T. Privalov, L. C. Sun, B. Åkermark, J. H. Liu, Y. Gao, M. Wang, Inorg. Chem., 2007, 46, 7075-7086.

[76] Y. Gao, T. Åkermark, J. H. Liu, L. C. Sun, B. Åkermark, J. Am. Chem. Soc., 2009, 131, 8726-8727.

[77] B. Lassalle-Kaiser, C. Hureau, D. A. Pantazis, Y. Pushkar, R. Guillot, V. K. Yachandra, J. Yano, F. Neese, E. Anxolabéhère-Mallart, Energy Environ. Sci., 2010, 3, 924-938.

[78] R. Gupta, T. Taguchi, B. Lassalle-Kaiser, E. L. Bominaar, J. Yano, M. P. Hendrich, A. S. Borovik, Proc. Natl. Acad. Sci. USA, 2015, 112, 5319-5324.

[79] W. T. Lee, S. B. Muñoz III, D. A. Dickie, J. M. Smith, Angew. Chem. Int. Ed., 2014, 53, 9856-9859.

[80] D. W. Crandell, S. Xu, J. M. Smith, M. H. Baik, Inorg. Chem., 2017, 56, 4435-4445.

[81] Y. Y. Li, K. Ye, P. E. M. Siegbahn, R. Z. Liao, ChemSusChem, 2017, 10, 903-911.

[82] M. A. Luna, F. Moyano, L. Sereno, F. D'Eramo, Electrochim. Acta, 2014, 135, 301-310.

[83] W. Schöfberger, F. Faschinger, S. Chattopadhyay, S. Bhakta, B. Mondal, J. A. A. W. Elemans, S. Müllegger, S. Tebi, R. Koch, F. Klappenberger, M. Paszkiewicz, J. V. Barth, E. Rauls, H. Aldahhak, W. G. Schmidt, A. Dey, Angew. Chem. Int. Ed., 2016, 55, 2350-2355.

[84] W. C. Ellis, N. D. McDaniel, S. Bernhard, T. J. Collins, J. Am. Chem. Soc., 2010, 132, 10990-10991.

[85] F. T. de Oliveira, A. Chanda, D. Banerjee, X. P. Shan, S. Mondal, L. Que Jr, E. L. Bominaar, E. Münck, T. J. Collins, Science, 2007, 315, 835-838

[86] M. Z. Ertem, L. Gagliardi, C. J. Cramer, Chem. Sci., 2012, 3, 1293-1299.

[87] R. Z. Liao, X. C. Li, P. E. M. Siegbahn, Eur. J. Inorg. Chem., 2014, 728-741.

[88] E. L. Demeter, S. L. Hilburg, N. R. Washburn, T. J. Collins, J. R. Kitchin, J. Am. Chem. Soc., 2014, 136, 5603-5606.

[89] C. Panda, J. Debgupta, D. D. Díaz, K. K. Singh, S. S. Gupta, B. B. Dhar, J. Am. Chem. Soc., 2014, 136, 12273-12282.

[90] J. L. Fillol, Z. Codolà, I. Garcia-Bosch, L. Gómez, J. J. Pla, M. Costas, Nat. Chem., 2011, 3, 807-813.

[91] Z. Codolà, I. Garcia-Bosch, F. Acuña-Parés, I. Prat, J. M. Luis, M. Costas, J. Lloret-Fillol, Chem. Eur. J., 2013, 19, 8042-8047.

[92] Z. Codolà, L. Gómez, S. T. Kleespies, L. Que Jr, M. Costas, J. Lloret-Fillol, Nat. Commun., 2015, 6, 5865. 
[93] B. M. Klepser, B. M. Bartlett, J. Am. Chem. Soc., 2014, 136, 1694-1697.

[94] W. A. Hoffert, M. T. Mock, A. M. Appel, J. Y. Yang, Eur. J. Inorg. Chem., 2013, 3846-3857.

[95] D. C. Hong, S. Mandal, Y. Yamada, Y. M. Lee, W. Nam, A. Llobet, S. Fukuzumi, Inorg. Chem., 2013, 52, 9522-9531.

[96] G. Panchbhai, W. M. Singh, B. Das, R. T. Jane, A. Thapper, Eur. J. Inorg. Chem., 2016, 3262-3268.

[97] W. P. To, T. W. S. Chow, C. W. Tse, X. G. Guan, J. S. Huang, C. M. Che, Chem. Sci., 2015, 6, 5891-5903.

[98] L. D. Wickramasinghe, R. W. Zhou, R. F. Zong, P. Vo, K. J. Gagnon, R. P. Thummel, J. Am. Chem. Soc., 2015, 137, 13260-13263.

[99] B. Das, A. Orthaber, S. Ott, A. Thapper, ChemSusChem, 2016, 9, 1178-1186.

[100] M. K. Coggins, M. T. Zhang, A. K. Vannucci, C. J. Dares, T. J. Meyer, J. Am. Chem. Soc., 2014, 136, 5531-5534.

[101] D. K. Dogutan, R. McGuire Jr, D. G. Nocera, J. Am. Chem. Soc., 2011, 133, 9178-9180.

[102] M. Z. Ertem, C. J. Cramer, Dalton Trans., 2012, 41, 12213-12219.

[103] W. Z. Lai, R. Cao, G. Dong, S. Shaik, J. N. Yao, H. Chen, J. Phys. Chem. Lett., 2012, 3, 2315-2319.

[104] B. Wang, Y. M. Lee, W. Y. Tcho, S. Tussupbayev, S. T. Kim, Y. Kim, M. S. Seo, K. B. Cho, Y. Dede, B. C. Keegan, T. Ogura, S. H. Kim, T. Ohta, M. H. Baik, K. Ray, J. Shearer, W. Nam, Nat. Commun., 2017, $8,14839$.

[105] H. T. Lei, A. L. Han, F. W. Li, M. N. Zhang, Y. Z. Han, P. W. Du, W. Z. Lai, R. Cao, Phys. Chem. Chem. Phys., 2014, 16, 1883-1893.

[106] L. Xu, H. T. Lei, Z. Y. Zhang, Z. Yao, J. F. Li, Z. Y. Yu, R. Cao, Phys. Chem. Chem. Phys., 2017, 19, 9755-9761.

[107] H. L. Sun, Y. Z. Han, H. T. Lei, M. X. Chen, R. Cao, Chem. Commun., 2017, 53, 6195-6198.

[108] H. T. Lei, C. Y. Liu, Z. J. Wang, Z. Y. Zhang, M. N. Zhang, X. M. Chang, W. Zhang, R, Cao, ACS Catal., 2016, 6, 6429-6437.

[109] Z. J. Wang, H. T. Lei, R. Cao, M. N. Zhang, Electrochim. Acta, 2015, 171, 81-88.

[110] A. Han, H. X. Jia, H. Ma, S. F. Ye, H. T. Wu, H. T. Lei, Y. Z. Han, R. Cao, P. W. Du, Phys. Chem. Chem. Phys., 2014, 16, 11209-11217.

[111] D. Wang, J. T. Groves, Proc. Natl. Acad. Sci. USA, 2013, 110, 15579-15584.

[112] T. Nakazono, A. R. Parent, K. Sakai, Chem. Commun., 2013, 49, 6325-6327.

[113] T. Nakazono, A. R. Parent, K. Sakai, Chem. Eur. J., 2015, 21, 6723-6726.

[114] D. J. Wasylenko, C. Ganesamoorthy, J. Borau-Garcia, C. P. Berlinguette, Chem. Commun., 2011, 47, 4249-4251.
[115] D. J. Wasylenko, R. D. Palmer, E. Schott, C. P. Berlinguette, Chem. Commun., 2012, 48, 2107-2109.

[116] B. Das, A. Orthaber, S. Ott, A. Thapper, Chem. Commun., 2015, 51, 13074-13077.

[117] I. Siewert, J. Gałęzowska, Chem. Eur. J., 2015, 21, 2780-2784.

[118] Y. K. Zhao, J. Q. Lin, Y. D. Liu, B. C. Ma, Y. Ding, M. D. Chen, Chem. Commun., 2015, 51, 17309-17312.

[119] H. A. Younus, N. Ahmad, A. H. Chughtai, M. Vandichel, M. Busch, K. Van Hecke, M. Yusubov, S. X. Song, F. Verpoort, ChemSusChem, 2017, 10, 862-875.

[120] R. Xiang, Y. Ding, J. W. Zhao, Chem. Asian J., 2014, 9, 3228-3237.

[121] R. Cao, H. Y. Ma, Y. V. Geletii, K. I. Hardcastle, C. L. Hill, Inorg. Chem., 2009, 48, 5596-5598.

[122] Y. Z. Han, Y. Z. Wu, W. Z. Lai, R. Cao, Inorg. Chem., 2015, 54, 5604-5613.

[123] M. Zhang, M. T. Zhang, C. Hou, Z. F. Ke, T. B. Lu, Angew. Chem. Int. Ed., 2014, 53, 13042-13048.

[124] G. Y. Luo, H. H. Huang, J. W. Wang, T. B. Lu, ChemSusChem, 2016, 9, 485-491.

[125] J. W. Wang, X. Q. Zhang, H. H. Huang, T. B. Lu, ChemCatChem, 2016, 8, 3287-3293.

[126] J. Masud, P. C. Ioannou, N. Levesanos, P. Kyritsis, M. Nath, ChemSusChem, 2016, 9, 3128-3132.

[127] L. Wang, L. L. Duan, R. B. Ambre, Q. Daniel, H. Chen, J. L. Sun, B. Das, A. Thapper, J. Uhlig, P. Dinér, L. C. Sun, J. Catal., 2016, 335, 72-78.

[128] S. M. Barnett, K. I. Goldberg, J. M. Mayer, Nat. Chem., 2012, 4, 498-502.

[129] T. Zhang, C. Wang, S. B. Liu, J. L. Wang, W. B. Lin, J. Am. Chem. Soc., 2014, 136, 273-281.

[130] M. T. Zhang, Z. F. Chen, P. Kang, T. J. Meyer, J. Am. Chem. Soc., 2013, 135, 2048-2051.

[131] J. S. Pap, Ł. Szyrwiel, D, Srankó, Z. Kerner, B. Setner, Z. Szewczuk, W. Malinka, Chem. Commun., 2015, 51, 6322-6324.

[132] P. Garrido-Barros, I. Funes-Ardoiz, S. Drouet, J. Benet-Buchholz, F. Maseras, A. Llobet, J. Am. Chem. Soc., 2015, 137, 6758-6761.

[133] K. J. Fisher, K. L. Materna, B. Q. Mercado, R. H. Crabtree, G. W. Brudvig, ACS Catal., 2017, 7, 3384-3387.

[134] M. K. Coggins, M. T. Zhang, Z. F. Chen, N. Song, T. J. Meyer, Angew. Chem. Int. Ed., 2014, 53, 12226-12230.

[135] R. J. Xiang, H. Y. Wang, Z. J. Xin, C. B. Li, Y. X. Lu, X. W. Gao, H. M. Sun, R. Cao, Chem. Eur. J., 2016, 22, 1602-1607.

[136] F. F. Chen, N. Wang, H. T. Lei, D. Y. Guo, H. F. Liu, Z. Y. Zhang, W. Zhang, W. Z. Lai, R. Cao, Inorg. Chem., 2017, 56, 13368-13375.

\title{
单核第一过渡周期金属水氧化催化剂
}

\author{
王 妮 ${ }^{\mathrm{a}}$, 郑浩铨 ${ }^{\mathrm{a}}$, 张 伟 ${ }^{\mathrm{a}}$, 曹 点 ${ }^{\mathrm{a}, \mathrm{b}, *}$ \\ 陕西师范大学化学化工学院应用表面与胶体化学教育部重点实验室, 陕西西安710119 \\ ${ }^{\mathrm{b}}$ 中国人民大学理学院化学系, 北京100872
}

\begin{abstract}
摘要: 由于传统化石能源的不可再生性, 其储量日益减少. 同时, 传统化石能源的使用对环境产生了巨大影响, 给人类社会 带来了一系列问题, 包括温室效应、酸雨等. 因此, 进入二十一世纪以后, 人类面临着日益严峻的能源危机和环境问题, 寻 找清洁、高效的替代能源已经迫在眉睫. 太阳能被认为是一种洁净的可再生能源. 自然界通过光合作用将太阳能转化为化 学能, 在这一过程中, 水被氧化产生氧气, 同时释放出的电子和质子通过和二氧化碳作用生成碳水化合物. 为了模拟这一 过程, 人工光合作用可以直接将电子和质子结合形成氢气. 由此生成的氢气也被认为是洁净的可再生能源, 因为在其燃烧 过程中只产生水. 因此, 通过光致水分解析氢析氧的人工光合作用受到了越来越广泛的重视.
\end{abstract}


水分解可以分为两个独立的半反应, 即水的氧化析氧和水的还原析氢. 水的氧化无论在热力学还是动力学方面, 都存

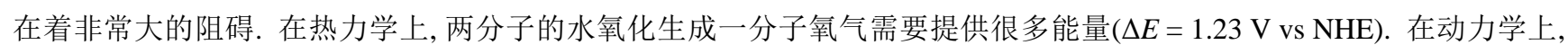
由于涉及到四个氢原子和两个氧原子的重组, 并且涉及到氧氧键形成并释放出一分子氧气, 因此水氧化是一个非常缓慢的 过程. 在自然界, 水的氧化主要发生在光合作用中, 在绿色植物的叶绿体中完成. 通过对光合作用的研究, 科学家们发现氧 气的产生由光系统II (PSII)中的释氧中心来完成. 释氧中心是一个钙锰簇合物, 由四个锰和一个钙组成 $\left(\mathrm{Mn}_{4} \mathrm{CaO}_{x}\right)$. 自然界 水分解产生氧气的过程给了我们很大启示, 对设计和研究高效稳定的水氧化催化剂具有一定的指导意义.

目前水氧化催化剂主要有两大类. 第一类是基于材料的水氧化催化剂. 该类催化剂的催化效率高, 过电势小, 但是对 水氧化催化过程的机理缺乏深入研究. 第二类是基于金属配合物的分子催化剂. 相比基于材料的催化剂, 分子催化剂具有 以下特点: (1)分子催化剂的结构可以通过实验手段表征清楚; (2)可以结合光谱对水氧化的机理进行深入研究, 可以对催 化过程中间体进行表征; (3)催化剂的结构可以从分子水平上进行修饰, 因此可以更好地研究催化效率与结构之间的关系, 为设计高效、稳定的催化剂提供必要信息; (4)比较容易组装成分子器件从而应用到实际的水氧化装置中; (5)通过实验与 理论的结合, 对氧氧成键提出新的认识与理解.

近几年来,一些单核的金属配合物逐渐被发现可以高效、稳定地催化水氧化. 研究表明,一些基于钉和铱的催化剂具 有良好的催化活性, 但由于金属钉和铱储量少、价格昂贵等因素, 限制了该类催化剂的大量使用. 由于第一过渡系金属元 素具有储量丰富、安全无毒、廉价易得等优势, 第一过渡周期金属化合物逐渐成为科学家们研究的热点. 近几年来, 基于 第一过渡系金属的水氧化催化剂已经有大量报道.

本文主要总结了近几年来基于第一过渡系金属的单核水氧化分子催化剂. 通过对催化机理进行深入的讨论, 特别是 对氧氧成键的总结, 本文将对设计合成结构新颖、具有高催化效率和良好稳定性的水氧化分子催化剂提供理论依据.

关键词: 水氧化; 氧-氧成键; 析氧; 第一过渡周期金属; 电催化

收稿日期: 2017-11-06. 接受日期: 2017-12-15. 出版日期: 2018-02-05.

*通讯联系人. 电子信箱: ruicao@ruc.edu.cn

本文的电子版全文由Elsevier出版社在ScienceDirect上出版(http://www.sciencedirect.com/science/journal/18722067). 